\title{
O LABOR DA MISION BIOLOXICA DE PONTEVEDRA ATA 1936 \\ E A REFORMA DA AGRICULTURA GALEGA EN CRUZ GALLASTEGUI UNAMUNO
}

\author{
Por \\ MIGUEL CABO VILLAVERDE ${ }^{1}$.
}

Nunha foto tomada o 25 de xullo de 1931 en Vigo, un home de paxariña aparece entre os Castelao, Paz-Andrade, Suárez Picallo, Alonso Ríos... radiantes na celebración do primeiro Día de Galiza no novo réxime; é o vasco Gallástegui, arropado por varias das principais figuras do galeguismo conformando unha imaxe certamente cargada de simbolismo, porque o PG (que se constituirá en decembre dese ano) vai intentar «apropiarse» da institución que el preside para dar solidez e empaque científico ás súas propostas en materia agraria ${ }^{2}$. Entre as carencias da súa primeira etapa en Santiago e a penuria da guerra civil e a postguerra, a Misión Biolóxica vai alcanzar nos anos da República o seu máximo recoñecemento, e a superación da precariedade financeira que a lastraba dende a súa fundación

\footnotetext{
' Becario predoctoral do Departamento de Historia II da Facultade de Xeografía e Historia da USC pola Consellería de Educación e Ordenación Universitaria da Xunta de Galicia. Para a realización desta investigación resultou fundamental o manexo dos fondos conservados na Misión Biolóxica e os hemerográficos e do Fondo do Estatuto de Autonomía do Instituto Padre Sarmiento de Santiago, e aproveito a oportunidade para agradece-las facilidades que se me brindaron en ámbolos dous centros.

${ }^{2}$ A imaxe en cuestión está reproducida en PAZ ANDRADE (1982: 319).
}

"CUADERNOS DE ESTUDIOS GALLEGOS", Tomo XLIV, Fascículo 109, Santiago 1997. 
permitiralle progresar en varias liñas de investigación e articula-los medios para que o traballo científico dera o salto do laboratorio á práctica agrícola cotiá.

Este traballo vaise estructurar en tres apartados, ocupándome no primeiro deles da historia da Misión ata a guerra civil evitando, por supérfluo e redundante, repetir datos dabondo coñecidos ${ }^{3}$. Unha vez conscentes do labor que levou a cabo na M.B., tentaremos dar o segundo paso: averiguar a qué idea de conxunto respondían esas investigacións sobre o millo, a pataca ou o porcino, que en si mesmas eran xa importantes (pensemos no feito de sermos en 1927 o primeiro lugar de Europa onde se obtiveron millos híbridos, nesta terra onde semella que toda novidade científica debe chegar en forma de graciosa concesión), pero que cobran todo o seu significado se se insertan na concepción xeral da agricultura galega que as animaba. Por último, deterémonos no xogo político que deron as súas propostas, os apoios que atopou, os indiferentes e os detractores, que tamén os houbo, aínda que poucos e eclipsados polas louvanzas.

\section{A MISION BIOLOXICA DE GALICIA, 1921-1936.}

Como é ben sabido, en 1920 a Junta de Ampliación de Estudios fixo pública a súa intención de instalar laboratorios científicos no que en Madrid se chamaban as provincias, invitando a todo tipo de entidades oficiais e privadas a que participasen na empresa. A Sociedad Económica de Amigos del País de Santiago, a instancias de Juan López Suárez, ofrece a súa colaboración e a proposta resulta aceptada, sendo nisto clave o papel do médico monfortino, que se entrevista con Ramón y Cajal e saca parti-

\footnotetext{
${ }^{3}$ Sobre a Misión pódense consultar, entre outros, o número especial 25-30 (1962) da Revista de Economía de Galicia, as voces «Gallástegui» e «Misión Biológica» da G.E.G., FERNANDEZ PRIETO (1989 e 1992), o ciclo de conferencias organizado pola Deputación de Pontevedra (VVAA, 1985), a voz «Gallástegui» en FRAGA VAZQUEZ e DOMINGUEZ (1993: 122-127) a cargo de Francisco Díaz-Fierros Viqueira e o artigo de BARREIRO GIL (1979) na Revista Galega de Estudios Agrarios.
}

"CUADERNOS DE ESTUDIOS GALLEGOS", Tomo XLIV, Fascículo 109, Santiago 1997. 
do dos seus vínculos familiares con Castillejo, secretario da $\mathrm{JAE}^{4}$. Un Comité formado polo presidente da Sociedad Económica (José Rivero de Aguilar), os propios Gallástegui e López Suárez, Rof Codina e o enxeñeiro forestal Areses dirixiría e controlaría en nome da Junta os traballos da Misión (repárese na denominación tan do gusto da época) ${ }^{5}$.

López Suárez, que trabara amistad con Gallástegui e xa lle xestionara unha bolsa en 1918 para poder seguir formándose nos Estados Unidos, está vencellado pois á Misión Biolóxica dende a súa mesma fundación, e será durante corenta anos o principal valedor do que el consideraba «uno de mis mayores aciertos en mi vida, y de mis mayores satisfacciones ${ }^{6}$. Durante toda a súa vida Gallástegui manterá unha relación constante con López Suárez, que será para él mentor espiritual e pano de bágoas, e non poucas veces un auxilio económico seu servirá para salvar algún proxecto da Misión que corría o risco de irse a pique ante a mezquindade das institucións públicas? ${ }^{7}$.

Entre abril de 1921 e finais de 1926 a Misión terá a súa sede en Santiago, concretamente nas dependencias da moribunda Escola de Veterinaria. A escasez, en tódolos sentidos, marcará esta primeira etapa, e obrigará a concentra-los limitados recursos nuns poucos temas considerados prioritarios para a agricultura galega do momento. Pensemos que Gallástegui

\footnotetext{
${ }^{4}$ López Suárez estaba casado coa súa irmá Mariana Castillejo. Pódense consulta-las voces «López Suárez» e «Gallástegui» na G.E.G., obra de Filgueira Valverde e Antonio Odriozola respectivamente, e sobre a instalación da Misión aporta moitos datos a colaboración de Benito Sánchez Rodríguez en VVAA (1985: 43-66).

${ }^{5}$ Carta de Ramón y Cajal a López Suárez (10-VIII-1921), AMB. Precisamente na súa petición a Sociedad Económica apuntaba entre as razóns que apoiaban a instalación en Santiago a colaboración que prestarían Rof Codina (o seu laboratorio e o seu ficheiro de datos) e Areses (os terreos do viveiro de Areas-Tui), aparte da cobertura científica que proporcionaría a Escola de Veterinaria.

${ }^{6}$ Carta de López Suárez a Antonio Odriozola (3-I-1966), Carpeta Legajo c) y legajo d), AMB. Gallástegui coñecera en Alemaña (estudiou na Escola Superior de Agricultura de Hohenheim entre 1910 e 1914) a Julio López Suárez, quen logo lle presentou ó seu irmán (v. voz «López Suárez» na G.E.G., tomo 15, pp. 93-97).

${ }^{7}$ A correspondencia, de frecuencia máis que mensual, recollida no F.L.S. do AHUS é boa proba da influencia que sobre Gallástegui tiña López Suárez, a quen lle consulta calqueira decisión que precise tomar; o contido da morea de cartas do devandito Fondo constitúe a mellor testemuña do inxente labor de mecenazgo que este home xogou en favor de innumerables iniciativas culturais e científicas.
}

"CUADERNOS DE ESTUDIOS GALLEGOS", Tomo XLIV, Fascículo 109, Santiago 1997. 
somentes contaba cun auxiliar de laboratorio ${ }^{8}$, que a falta de terreos limitaba as experimentacións e que na Universidade autista da época só atopou certa colaboración no biólogo Luis Iglesias. A aspiración de que o seu traballo tivese aplicación inmediata entre os campesiños e de responder o máis fielmente ás súas necesidades non debemos dala por sentada por natural que nos pareza hoxe, pois non estaban tan lonxanos os tempos nos cales os técnicos pretendían que a agricultura se adaptase a eles en vez de ó contrario9.

As prioridades van ser dúas, o millo por unha banda, cos estudios sobre hibridación que serán os que maior sona lle dean á Misión, e por outra o castiñeiro, devastado pola enfermidade criptogámica da «tinta» que chegara a Galicia ó redor de 1875 e desprazara definitivamente a esa árbore do papel protagonista que tiña na economía rural tradicional. Gallástegui e o seu colaborador Ramón Blanco (daquela Xefe da Sección Agronómica de Lugo) van dirixir un escrito ó goberno aconsellando a prohibición da introducción de castiñeiros asiáticos polo risco de que á tinta se sumase o fungo Endothia parasitica, petición que foi atendida (Gaceta do 21-XII$1922)^{10}$. Así como os traballos co millo van atopar continuidade na etapa pontevedresa, os intentos de obter híbridos do castiñeiro do país (castanea sativa) con variedades asiáticas que foran resistentes á praga non foron coroados polo éxito (os híbridos eran menos vigorosos e só un pouco máis resistentes que os do país), aínda que constituían un paso na dirección correcta, e non serían retomados pola Misión ata os anos cincoenta

\footnotetext{
${ }^{8}$ Inicialmente estaba previsto que se incorporara á Misión o Catedrático de Zooloxía da Universidade de Murcia Fernández Noninez, pero finalmente non o fixo (VVAA, 1985: 48).

${ }^{9}$ Era o que a afiada pruma de Valeriano Villanueva chamaba «candoroso modernismo», predominante na primeira década do século XX, e que na Granxa Agrícola de A Coruña estivo representado polo seu director ata 1904 Marceliano Alvarez Muñiz; para estas cuestións, FERNANDEZ PRIETO (1992).

${ }^{10}$ BLANCO (1925). Ramón Blanco e Rof Codina (ligado a unha Casa distribuidora de castiñeiros xaponeses) mantiveron unha tensa polémica ó longo de 1922 e 1923 sobre a pertinencia de tal medida. Por outra banda, o interese de Gallástegui polo tema viña xa de lonxe, porque cando aínda estaba a estudiar na Estación Agronómica de New Haven publicou en El Pueblo Vasco un artigo sobre a Endothia parasitica ou «chancro» do castiñeiro. Un estudio completo destas cuestións pode atoparse en FERNANDEZ DE ANA MAGAN et al. (1995).
}

"CUADERNOS DE ESTUdIOS GALLEGOS", Tomo XLIV, Fascículo 109, Santiago 1997. 
gracias ás investigacións de Ernesto Viéitez ${ }^{11}$.

A precariedade de medios será mitigada en parte coa colaboración por parte de particulares, e así Areses facilitou os terreos do viveiro forestal de Areas-Tui para as investigacións sobre a «tinta», Rof Codina como asesor técnico da Federación Católica provincial fixo un chamamento para que lle proporcionaran espigas para obter variedades de millo, o prohome do catolicismo social e membro da Sociedad Económica Díaz de Rábago permitiu que se sementara millo nunha finca súa da Póboa de Caramiñal, etc ${ }^{12}$.

Nos anos nos que a Misión estivo en Santiago estudiáronse 46 variedades de millo galegas e 26 procedentes dos EEUU, aillándose máis dun centenar de liñas puras para producir híbridos simples e dobres e fixéronse estudios sobre caracteres hereditarios como a esterilidade feminina, sempre en contacto coa Stazione de Maiscoltura de Bergamo e a Connecticut Agricultural Experiment Station (onde traballaba o antigo mestre de Gallástegui D.F. Jones) ${ }^{13}$. Asimesmo Gallástegui impartiu un cursillo de mendelismo na Escola de Veterinaria en abril de 1922 e foi formando na Xenética (pensemos que non foi incorporada como asignatura ós plans de

1 Sobre esta enfermidade vid. voz «castiñeiro» na G.E.G. (tomo 5, pp.223-228), precisamente a cargo do Profesor Viéitez Cortizo, e o citado FERNANDEZ DE ANA MAGAN et al. (1995). A loita contra a enfermidade, ocasionada polos.fungos Phytophtora cinamomi e $P h$. cambivora, foi desenvolvida nos anos trinta e corenta exclusivamente pola Estación de Fitopatoloxía de A Coruña; o seu director, Pedro Urquijo Landaluce, creou a base de sales de cobre o primeiro tratamento efectivo contra a «tinta», pero o que chegou a ser recoñecido internacionalmente como «método Urquijo» era moi difícil de aplicar a gran escala (esixía un tratamento individual árbore por árbore) e finalmente a EFA enfocou a cuestión tamén pola vía da hibridación, aínda que en absoluta desconexión coas investigacións paralelas da Misión; sobre este tema pode consultarse a nosa memoria de licenciatura (CABO VILLAVERDE, 1994: 152-162) e un artigo de próxima aparición na revista Ingenium no que presentamos a traxectoria dese centro.

${ }^{12}$ Memorias 1921-22 e 1922-25, Carpeta Leg. A, AMB.

${ }^{13}$ Memoria referente al funcionamiento de la Misión Biológica de Galicia, obra de Marcelino de Arana y Franco en 1935 e conservada no AMB e no AHUS (Serie Histórica A-340). En 1930 levábanse xa ensaiadas 174 variedades, delas 153 galegas, e o resto francesas, norteamericanas e italianas; as destas dúas últimas procedencias deberon ser desechadas por ter un ciclo vexetativo demasiado largo para o clima galego, e das 174 seguíanse cultivando en setembro de 1930 unicamente 8 variedades de gran amarelo e 6 de branco (Memoria correspondiente a los cursos 1928-9 y 1929-30, JAE, 1930, páx. 283).

"CUADERNOS DE ESTUDIOS GALLEGOS", Tomo XLIV, Fascículo 109, Santiago 1997. 
estudio ata finais dos anos 20) a algúns técnicos que logo atoparemos ocupando cargos de responsabilidade en Galicia, como Ramón Blanco ou Andrés Corral ${ }^{14}$.

A situación da Misión vaise complicar por mor da supresión da Escola de Veterinaria, que en realidade era un feito anunciado dado o descenso continuo de matriculados, e xa en 1921, o mesmo ano pois que se instala a M.B. nas súas dependencias (aínda que sen relación orgánica co centro) o deputado Moreno Tilve e varios concellais santiagueses solicitan que se adique a metade do seu edificio a Cuartel de Artillería ${ }^{15}$. Segundo RODRIGUEZ GARCIA (1994: 125) en marzo de 1923 produciuse a entrega de parte do edificio - que hoxe alberga o Parlamento de Galiciaó Exército, cesión que se completaría definitivamente en outubro de 1924. A Capitanía Xeral de A Coruña deu un permiso especial a Gallástegui para que continuara ata outubro de 1925 na parcela que facía as veces de horta, pero as dependencias que ocupaba no edificio debía deixalas antes do 1 de agosto dese ano $^{16}$.

\footnotetext{
${ }^{14}$ Cos coñecementos adquiridos en Alemaña e EEUU, Gallástegui aproveitou para obter entre 1922 e 1923 o título de Veterinario, profesión que non chegaría a exercer aínda que publicou en 1923 en Madrid un libriño de 26 páxinas titulado Herencia mendeliana en las capas del caballo. Repárese en que non tiña propiamente o de Enxeñeiro Agrónomo, o que será para el fonte continua de preocupacións e de discriminacións, como se pode entrever na súa correspondencia. As rencillas corporativistas entre veterinarios e enxeñeiros serán unha constante durante a primeira metade de século, alcanzando o seu punto máximo coa creación en 1931 da Dirección Xeral de Gandería por Gordón Ordás, e Gallástegui non puido evitar verse afectado por esa guerra. Resulta significativo que a pesares do seu nivel científico non fora invitado nunca a colaborar na revista Agricultura (onde escribían con asiduidade os técnicos dos centros coruñeses como Escauriaza ou Urquijo) nin ó I Congreso Nacional de Ingeniería Agronómica, celebrado con gran pompa en Madrid en 1950. Na súa lembranza de Gallástegui no número extraordinario de homenaxe da Revista de Economía de Galicia (n 25-30, 1962), López Suárez fai referencia a que os enxeñeiros agrónomos non viron con bos ollos a mesma creación da M.B., actitude da que habería que exceptuar a Ramón Blanco.

${ }^{15}$ Nun fermoso artigo na revista agrocatólica mindoniense Acción Social ( ${ }^{\circ} 60,15$ V-1921), Rof Codina alertaba sobre tales proxectos e suxería diversas medidas a tomar para revitaliza-la Escola. Afirmaba o veterinario catalán:

«Ningún pueblo ha progresado ni progresará, porque aumenten en una o más unidades regimentales, su guarnición militar; pero en cambio todo centro de enseñanza, de estudio, de investigación o experimentación, más tarde o más temprano rinde sus frutos y produce la transformación del país que se perseguía con su creación».

${ }^{16}$ Carpeta «Legajo c) y Legajo d)», AMB.
}

"CUADERNOS DE ESTUDIOS GALLEGOS", Tomo XLIV, Fascículo 109, Santiago 1997. 
$\mathrm{O}$ arcebispado cedeu temporalmente unhas parcelas no Manicomio de Conxo que permitiron ir tirando durante algún tempo, mentras se facían xestións ante as Deputacións. Nunha nota dirixida ás de Coruña e Lugo, aparte de resumi-lo feito ata o momento co millo e co castiñeiro, precísanse os proxectos de futuro que Gallástegui tiña pensado acometer de arranxala súa situación: obter unha variedade de toxo de follas dulces para alimentación do gando, traballar con variedades de pataca e crear unha raza leiteira e outra de engorde de gando galego, «dado que está absolutamente probado científicamente y en el terreno de la práctica que por el procedimiento de paradas, sementales y concursos no se puede llegar a resultado alguno efectivo» ${ }^{17}$. Gallástegui solicitaba un mínimo de 4.000 pesetas a cada Deputación para pago do arrendo do terreo, personal e gastos de cultivo e material. Se esa cifra subía ata 10.000 se comprometía a entrar máis a fondo nas cuestións gandeiras, sempre que lle garantisen a subvención polo menos por 15 anos.

Sen embargo sería finalmente a Deputación de Pontevedra a que faría a proposta máis consistente: a finca «La Tablada» (3ha., delas dúas cultivables), 5.000 pta. anuais e unha cifra similar aportada pola Deputación de Ourense, producíndose en 1927 o traslado. As xestións de Ramón Blanco ante Daniel de la Sota, presidente da Deputación Pontevedresa, parecen ter sido claves, ademais de que nesa provincia o cultivo do millo tiña maior importancia ${ }^{18}$. Ata o ano seguinte non atoparía a Misión o seu emprazamento definitivo, na finca e pazo de Gandarón na parroquia de Salcedo, onde aínda continúa hoxendía ${ }^{19}$. Todos estes traslados non po-

${ }^{17}$ Idem. No Primer Congreso de Economía Galega, celebrado en Lugo en 1925, Gallástegui presentou as conclusións da Sección $1^{\text {a }}$ de Gandería xuntamente con Ramón Blanco e afirmou tamén que a organización de paradas de sementais tal como se facían naquel momento non era de ningunha utilidade (Primer Congreso de Economía Galle$g a, 1991: 82)$. En cambio non participou, significativamente, na Sección de Agricultura.

${ }^{18} \mathrm{Voz}$ «Gallástegui» en G.E.G., páx.95. Por outra banda Galicia Agraria, órgano do agrarismo católico coruñés, criticou a pasividade da Deputación coruñesa con motivo do traslado da Misión, en contraste coa de Pontevedra que impulsaba a repoboación forestal e agora a M.B., da que destacaba unicamente a teima de Gallástegui por convertir a Galicia en exportadora de millo. (GA n ${ }^{\circ}$ 4, 15-II-1927). Nese mesmo número, comentando a pugna entre os intereses trigueiros e os das rexións gandeiras na Asemblea Cerealícola celebrada en Madrid, a revista anima a levar á práctica os consellos de Gallástegui (páx.22).

${ }^{19} \mathrm{~A}$ finca foi adquirida por 350.000 pesetas pola Deputación e tiña unha extensión de dez ha. (delas oito aptas para o cultivo) dentro dos muros e dúas máis fóra deles (EPG 10-IV-1930).

"CUADERNOS DE ESTUDIOS GALLEGOS", Tomo XLIV, Fascículo 109, Santiago 1997. 
dían deixar de afectar ó traballo da M.B., e Gallástegui amosa a López Suárez por esta época o seu descontento e os seus temores ante a perspectiva do que pasaría de cesar La Sota no seu cargo ${ }^{20}$. Gallástegui acaricia - e non será a última vez- a idea de deixa-la Misión e adicarse á empresa privada (recibiu algunha oferta en firme) e ademais nin sequera ten a seguridade de seguir no cargo de director en Salcedo, dado que a lexislación favorecería a calquer outro candidato que posuíse o título de Enxeñeiro Agrónomo (éstes considerabanlle — nas súas propias verbas- un «intruso» $)^{21}$.

Gallástegui víase especialmente afectado pola situación de interinidade creada por estas cuestións, que impedía planificar traballos a largo prazo, e polo feito de non poder concentrarse nas súas investigacións polas tarefas de xestión que tiña que asumir e a distracción que supuñan as continuas negociacións e tiras e afrouxa coas distintas administracións. A principios de 1930 La Sota es sustituído por Manuel Casas Medrano na Deputación de Pontevedra e pouco tarda en entrar en conflicto con Gallástegui polo seu proxecto de primar na M.B. a ensinanza sobre a investigación. O director da Misión consideraba prioritaria esta última, e que en todo caso a ensinanza debería orientarse cara á formación de capataces especializados de entre 20 e 30 anos e non á de rapaces de entre 14 e 16 como pretendía Casas ${ }^{22}$. A partir desta controversia Casas Medrano embárcase nunha serie de represalias que exemplifican a inexistencia dunha planificación rigurosa da política agraria por parte da Administración, pois a existencia dun centro víase ameazada por unha cuestión case

${ }^{20}$ Carta de Gallástegui a López Suárez 9-XI-1927, F.P.L.S.

${ }^{21}$ Idem, 14-X-1928, e 8-I-1929. Tamén fixo xestións para obter algún posto nos servicios agronómicos de Guipúzcoa (carta a L.S. 29-VII-1929). Dacordo cos datos contidos na correspondencia con López Suárez, Gallástegui chegou a presenta-la dimisión formalmente en dúas ocasións (1929 e 1930) neste período de incertidume, pero nos dous casos foi convencido para retirala. De feito cando Casas Medrano releva a La Sota ó frente da Deputación, Gallástegui confésalle a López Suárez que no fondo alegraríalle que decidise pecha-la Misión (carta 2-III-1930).

${ }^{22}$ PORTO UCHA (1986: 316). A única experiencia deste tipo tivo lugar na M.B. en 1931 con seis obreiros becarios (catro pola Deputación de Pontevedra e un polas de Ourense e Coruña) en réxime de internado, pero a pesares do seu bo comportamento Gallástegui considerou que o experimento alterara a marcha do centro e decidiu que as únicas ensinanzas impartidas a partir daquel momento serían as dos técnicos; Memoria... de 1935, AHUS, A-340.

"CUADERNOS DE ESTUDIOS GALLEGOS", Tomo XLIV, Fascículo 109, Santiago 1997. 
persoal $^{23}$.

Casas maniobrou por unha banda para que o Instituto de Cerealicultura non consignase a subvención de 50.000 pesetas á Misión correspondente a 1930 (en virtude co establecido nun R.D. do ano anterior) e só a actuación de Rodríguez de Viguri - daquela ministro de Economía - puido evitalo (ademais ese mesmo ano concedeulle a subvención para ir mercar un lote de porcos Large-White a Inglaterra). Máis grave foi a determinación da Comisión Permanente da Deputación de reclamarlle a finca de Salcedo á Misión ${ }^{24}$. Finalmente o conflicto resolveuse coa entrega por cinco anos da finca en xaneiro de 1931 á vez que a Deputación suprimía a subvención anual de 5.000 pta. que lle concedera ata entón ${ }^{25}$. Gallástegui laiase de que cando puido tomar de novo posesión da finca houbo que volver a mercar bois, carro, arados e incluso ferramentas porque todo o material desaparecera durante os meses (de outubro de 1930 a marzo de 1931) nos que a Deputación se fixera cargo de Salcedo, aparte da alteración que supuxo no calendario de sementeira ${ }^{26}$.

Este episodio tivo lugar xustamente cando a M.B. acababa de recibir un recoñecemento oficial indubitable, pois nun Decreto sobre fomento do cultivo do millo asignábaselle un papel clave na consecución do autoabastecemento nese cereal ${ }^{27}$. Considerando que fora o único centro do estado onde ata o momento se investigara a obtención de híbridos, o ámbito de actuación do Instituto de Cerealicultura non incluiría na práctica a Galicia e o litoral cantábrico, que cubriría a Misión. Ésta recibiría unha subvención anual de 50.000 pesetas a cambio de suministra-la

\footnotetext{
${ }^{23}$ Gallástegui tiña unha opinión pésima de Casas, e a López Suárez confésalle que desespera de poder facerlle entrar en razón (aludindo ironicamente á súa condición de Coronel xubilado); FPLS, carta 21-IV-1930.

${ }^{24} \mathrm{Na}$ sesión do 22-IX-1930 (PORTO UCHA, 1986: 345). Con anterioridade barallárase nada menos que a idea de adicar parte da finca de Salcedo a reformatorio de menores (EPG 4-VI-1930).

${ }^{25}$ En agosto de 1933 a Deputación decidiría a concesión de Salcedo á Misión por un mínimo de 20 anos.

${ }^{26}$ Carta a López Suárez, 23-IV-1931; F.P.L.S., e JUNTA PARA AMPLIACION DE ESTUDIOS E INVESTIGACIONES CIENTIFICAS (1933: 261).

${ }^{27}$ Gaceta 12-VI-1929; pode consultarse en GA n58, 15-VI-1929. En carta a López Suárez (31-X-1930) Gallástegui califica o Decreto de «intromisión», sen aportar maiores explicacións (F.P.L.S.).
}

"CUADERNOS DE ESTUDIOS GALLEGOS", Tomo XLIV, Fascículo 109, Santiago 1997. 
semente para esas provincias e de contribuír a formar a dous bolseiros enxeñeiros agrónomos. A importancia desa suma (aínda que non sería actualizada ata 1942 cando se duplicou) queda de relevo se a comparamos co presuposto total de 20.500 pesetas para 1927 (delas 10.500 proporcionadas pola JAE e 5.000 as Deputacións de Ourense e Pontevedra) e de 40.000 para 1928.

Non debemos esquece-lo feito de que a Misión recibía na preguerra subvencións de varias fontes, en concreto a JAE, o Ministerio como acabamos de ver e as Deputacións (máis nun momento dado o Concello e a Caixa de Aforros de Vigo), o cal significaba tamén a pugna de concepcións diversas sobre cal debía se-la súa orientación ${ }^{28}$. A remodelación do Padroado no ano 1931 constituiu un intento por poñer orde na administración do centro creando un marco onde poideran harmoniza-las súas posicións os diferentes organismos con intereses na Misión ${ }^{29}$. O Padroado definíase a si mesmo como «una especie de Ministerio de Relaciones Exteriores de la Misión biológica» que tería como misión o enlace coa poboación rural e cos organismos involucrados no seu sostemento ${ }^{30}$. Sen embargo non será quen de estar á altura deste cometido, pois se ben estableceuse que tería que reunirse polo menos unha vezó ano e redactar informes sobre a marcha da Misión, o certo é que non se volveu convocar ata marzo de 1935, e o Consello Directivo (creado o 22-III-1931) caeu na

${ }^{28}$ Entre 1931 e 1933 o Concello de Vigo puxo a disposición da M.B. unha finca na parroquia de Sárdoma e unha pequena subvención; no período crítico de 1930 Gallástegui considerou incluso a posibilidade de trasladar a Vigo a Misión se seguían os problemas coa finca de Salcedo (carta a López Suárez 7-XII-1930, F.P.L.S.). Gallástegui aproveitouna para sementar nela os millos de grán branco e reserva-los de gran amarelo para Salcedo, eliminando así a posibilidade de fecundacións indesexadas entre ámbalas dúas clases, pero finalmente debeu renunciar á finca porque o Concello non facía efectivos os fondos para o seu sostemento.

${ }^{29}$ Quedou constituído o 8 de marzo dese ano do seguinte xeito: Presidente Rodríguez Cadarso (rector da Universidade), Casas Medrano (pola Deputación de Pontevedra), Jacobo Varela Menéndez, Eladio Pérez Romero (Dept. Ourense), Daniel de la Sota, Jacobo Varela de Limia, Joaquín Martínez Chantrero (Presidente do SPS), Rof Codina, Fernando Taboada Zúñiga (agricultor de Sarria), Luis Patiño (Cámara Agr. Pontevedra), Aureliano Ferreiro (agricultor de Ourense), García Vidal, López Suárez, Rafael Areses e o propio Gallástegui. AHUS, A-340 Serie Histórica. O Padroado anterior formárase en maio de 1928, presidido por La Sota e con Gallástegui, López Suárez, Losada Diéguez, Areses e Aureliano Ferreiro (pola Deputación de Ourense) como vocais.

${ }^{30}$ Intervención de Rodríguez Cadarso, v. nota anterior.

"CUADERNOS DE ESTUDIOS GALLEGOS", Tomo XLIV, Fascículo 109, Santiago 1997. 
mesma inacción. En resumidas contas, o control efectivo da M.B. estaba en mans da Comisión de Estudios de Galicia da JAE, na que si estaba presente López Suárez (FERNANDEZ PRIETO, 1992: 143).

No que se refire a persoal a dotación da M.B. na súa etapa pontevedresa non era máis numerosa que a dos centros coruñeses (Estación de Fitopatoloxía e Granxa Agrícola) e semella insuficiente para as misións que tiña encomendadas; aparte do seu director contaba con Miguel Odriozola Pietas (formalmente asignado á Granxa da Coruña) e distintos bolseiros que complementaban no centro a súa formación, destacando o enxeñeiro José de la Venta —entre abril de 1931 e abril de 1933 - porque na práctica sustituiu a Gallástegui como director mentras estivo en Madrid nos comezos da República; o personal subalterno estaba composto por un total de cinco persoas á altura de 1935 e persoal administrativo non houbo ata abril de 1931, desempeñando logo tales funcións Alexandre Bóveda (do que Gallástegui tiña un excelente concepto) en 1931-33 e máis tarde un mecanógrafo e unha contable. Para termos un elemento de comparación, na Estación de Fitopatoloxía de A Coruña o seu director Urquijo Landaluce era antes da guerra o único titulado superior dunha plantilla composta por seis persoas, mentras a Granxa contaba con once, delas dous enxeñeiros agrónomos (CABO VILLAVERDE, 1994: 59).

Un rasgo a destacar do persoal da Misión era a súa formación nos centros punteiros no estranxeiro na especialidade de que se tratara, non só no caso do seu director senón tamén noutros como o becario Vicente Boceta (Xenética Animal na Escola de Agricultura de Berlín), Miguel Odriozola (porcino en Aberdeen,), etc.

As disponibilidades financeiras da Misión durante os anos trinta aumentaron considerablemente (FERNANDEZ PRIETO, 1992: 141), o que permitiu afronta-la creación en 1930 do Sindicato de Productores de Semillas, o organismo ideado por Gallástegui para dar difusión ós millos híbridos (e secundariamente outros cultivos) producidos na Misión ${ }^{31}$. O SPS era a resposta á demanda crecente por parte dos agricultores, imposible de cubrir cos recursos propios da M.B. Na primavera de 1928

\footnotetext{
${ }^{31} \mathrm{Na}$ Directiva do Sindicato Gallástegui e Cambronero (Xefe da Sección Agronómica provincial) eran vocais natos; o primeiro presidente foi Bernardino Fondevila, a quen sucedeu en 1934 Daniel de la Sota (BSPS n 9-11, 1-XII-1933); antes da guerra civil o último presidente sería Martínez Chantrero.
}

"CUADERNOS DE ESTUDIOS GALLEGOS", Tomo XLIV, Fascículo 109, Santiago 1997. 
repartíranse gratuitamente $900 \mathrm{~kg}$. de dobre híbrido de millo amarelo entre 115 agricultores, o ano seguinte foron dúas toneladas de millo branco entre 380 labregos e en 1930 algo máis de tres toneladas e media de millo amarelo e 1.230 kilos do branco, a 50 céntimos o kilogramo ${ }^{32}$. Sen embargo ese último ano os pedidos rebasaran as $25 \mathrm{Tm}$. por parte de 700 agricultores (EPG 10-IV-1930), o cal daba pe a pensar que chegara o momento de dar un salto cualitativo na distribución. De aí que se fundase o SPS sobre a base inicial de 17 agricultores que xuntaban en total unhas 20 ha. que sementaron con híbridos sinxelos suministrados gratuitamente pola Misión, elevándose en 1935 xa a 259 o número de socios.

Pode semellar unha cifra moi reducida pero hai que ter en conta que varios deses asociados non eran individuais senón sociedades agrarias ${ }^{33}$. Segundo os cálculos de Lourenzo Fernández Prieto a semente O.D.H. (Orixinal Dobre Híbrido) producida e comercializada polo Sindicato pasou de $16 \mathrm{Tm}$. no ano agrícola 1930-31 a $70 \mathrm{Tm}$. en 1934-35, o que calculando $40 \mathrm{~kg}$. como a cantidade necesaria para sementar unha hectárea suporía pasar de 400 ha. potencialmente sementadas con dobre híbrido a $1.750^{34}$.

Cada ano o Sindicato comunicaba á Misión a relación de socios que querían producir semente e o centro suministráballes os híbridos sinxelos e ademais un capataz estaba presente na sembra e na recolección. Deses híbridos sinxelos obteríanse logo os dobres. O maíz era desecado nos hórreos dos socios e ata febreiro o Sindicato non se facía cargo del. O SPS levaba a cabo unha vixilancia sobre as condicións de cultivo que deu lugar á expulsión de varios socios por non cumpri-los requisitos esixidos. En febreiro de 1933 apareceu o primeiro número do Boletín do Sindicato, que aspiraba a servir de enlace entre os seus asociados e a dar a coñece-

${ }^{32}$ Memoria... citada; AHUS Serie Histórica, A-340.

${ }^{33}$ HERVES SAYAR (1991: 157) sinala por exemplo que varias sociedades da Federación de Ponteareas foron socias do SPS. Contamos somentes cunha lista dos socios do Sindicato, en concreto unha relación dos dezasete socios fundadores aparecida nun artigo de Gallástegui no Boletín de Agricultura Técnica y Económica ( $\mathrm{n}^{\circ} 262$, outubro 1930) onde se destaca que foran elexidos «de prestigio y honorabilidad». Na lista atopamos entre outros a D. de la Sota, Martínez Chantrero, catro curas párrocos, a mesma granxa de Salcedo e a de Lourizán, cun carácter elitista que é de supoñer caracterizaría unicamente ó momento inicial.

${ }^{34}$ (FERNANDEZ PRIETO, 1992: 430). A Memoria Correspondiente a los cursos 1931 e 1932 da JAE infórmanos de que a cantidade distribuída no ano agrícola 1931-32 fora de $28 \mathrm{Tm}$.

"CUADERNOS DE ESTUDIOS GALLEGOS", Tomo XLIV, Fascículo 109, Santiago 1997. 
las investigacións da M.B. e os progresos agrícolas en xeral, realizando un gran labor divulgador. Terá periodicidade mensual ata a súa desaparición en xullo de 1936, colaborando nas súas páxinas non só o persoal da Misión senón tamén o dos Servicios Agronómicos das provincias galegas, o director da EFA Urquijo Landaluce e Luis Iglesias ${ }^{35}$.

Un aspecto que debe terse en conta é que da semente O.D.H. producida e comercializada polo SPS unicamente unha parte quedaba en Galicia, pois máis da metade ía para o resto do Estado, aínda que esto é por peso, porque por pedidos loxicamente predominaban os procedentes das provincias galegas (BSPS n 20 , III-1935). Os encargos de fóra de Galicia superaban sempre os 100 kilos, frente os de $5-10 \mathrm{~kg}$. dos agricultores locais, «lo cual si refleja el minifundismo de nuestros cultivos y por lo mismo, lo enormemente mayor de la dificultad de introducir innovaciones de cualquier clase en el campo gallego, demuestra también cuánto debe agrandarse nuestro esfuerzo hasta lograr ver difundidas en él las semillas producidas y seleccionadas por nuestra Misión Biológica de Galicia». Por poñer un exemplo, en 1935 a cantidade vendida polo Sindicato en Logroño superaba a distribuída en toda Galicia ${ }^{36}$.

Gallástegui comenta amargamente na súa correspondencia as dificultades adicionais que lle supón a estructura da propiedade en Galicia e en concreto en Pontevedra, que era onde se concentraba o radio de acción do Sindicato (concellos de Pontevedra, Porriño, Vilagarcía, Tui...). Compartía ó cento por cento a tese de López Suárez de que para evita-la dependencia dos vaivéns políticos a Misión debía acrecenta-lo seu grao de autofinanciación de xeito que as subvencións ocuparan un lugar secundario, e achacaba a non consecución dese obxectivo hacia 1933 como el previra á súa ausencia cando fora destinado ó Ministerio en Madrid pero sobre todo á división da propiedade («Estamos en la provincia más difícil de España. Mire que ni aún Alemania con su poder organizador ha podido crear cooperativas en algunas de sus zonas, análogas a Galicia») $)^{37}$.

${ }^{35}$ Deica o número 19 (febreiro de 1935) non son máis que catro follas, ata que a comezos dese ano pasa a unhas 15-20 en forma de caderniño e con ilustracións. Entre xullo de 1934 e febreiro de 1935 non se publicou debido a «trabajos inaplazables de quienes lo redactan y componen».

${ }^{36}$ Acta da Sesión da Xunta Xeral Ordinaria de 6-XI-1935, reproducida no BSPS n ${ }^{\circ}$ 26 (XI-XII 1935).

- ${ }^{37}$ Carta a López Suárez 16-VI-1935; F.P.L.S.; o mesmo escepticismo sobre o futuro do Sindicato noutra de 11-I-1936.

"CUADERNOS DE ESTUDIOS GALLEGOS", Tomo XLIV, Fascículo 109, Santiago 1997. 
Na súa correspondencia privada o director da Misión dista moito de profesa-la fe no cooperativismo que predica nos seus discurso públicos e nas súas colaboracións na prensa. En 1935, por exemplo, o Sindicato sementaba 33 ha. , pero a dispersión das parcelas multiplicaba os custos de transporte e vixilancia:

«En otra zona u otro país 33 hectáreas las reunen entre 6 agricultores cercanos lo que trae mucha simplificación de operaciones [...] El $70 \%$ de la semilla sale para otras regiones. En Galicia solo queda el $30 \%$. Esto indica muchas cosas» ${ }^{38}$.

Pensemos que no momento de funda-lo Sindicato Gallástegui calculara que para suministrar semente suficiente para sementar toda a superficie adicada ó millo en Galicia facían falta 1.600 hectáreas de terreo, é dicir, corenta e sete veces a superficie disponible en 1935 (aínda non tendo en conta que case as 3/4 da producción se distribuía fóra de Galicia) (EPG 10-IV-1930).

E sen embargo o Sindicato era unha fórmula moi válida para superar eses atrancos, por exemplo distribuíndo adubos en envases de menor capacidade que os que vendían as casas comerciais ${ }^{39}$.

${ }^{38}$ V. nota anterior. Aparte dos incentivos persoais, por outra banda completamente lexítimos, nas súas tentacións de desenvolve-la súa vida profesional lonxe de Galicia tamén está presente este factor. Isto apréciase por exemplo nunha carta a López Suárez o 4 de abril de 1940, aínda que hai que ter en conta que se trataba precisamente da peor época da Misión na súa historia; nela confiáballe a oferta que lle fixeran para ir traballar a Valladolid:

«Decía Bulmes [o xerente do Sindicato de Valladolid que lle fixera a oferta] y tenía razón, que nosotros no hemos sido ni seremos capaces de producir semillas en cantidad ni que nuestros resultados trasciendan más allá de unas hectáreas, debido a la división de la propiedad, a menos que yo mismo arriende y cultive fincas mayores, pero con menoscabo de mi trabajo [...] Nuestro esfuerzo no está en relación con la utilidad práctica que esos mismos resultados podrían tener en zonas de agricultura más amplia».

${ }^{39}$ BSPS no 19 (II-1935); en concreto envases que contiñan o adubo necesario para un ferrado de terra adicada ó millo; isto facíase cos nitroxenados e os potásicos, porque cos fosfatados non había necesidade porque xa respondían satisfactoriamente os comerciantes.

"CUADERNOS DE ESTUDIOS GALLEGOS", Tomo XLIV, Fascículo 109, Santiago 1997. 
Para a organización do Sindicato Gallástegui tivo moi presente o modelo dun organismo similar dependente da Estación de Sementes de Svalof (Suecia), que de feito visitou en 1929, xusto antes por tanto de funda-lo SPS, e o do Instituto de Xenética de Muncherberg (BSPS n ${ }^{\circ} 14-15$ e 1718). O Sindicato permitiría manter á marxe ás empresas privadas, porque en opinión de Gallástegui de dominar elas o mercado o fraude masivo (do estilo do que se producira no caso dos adubos) sería inevitable e minaría a confianza dos receptores da innovación ${ }^{40}$. Outra vantaxe evidente sería reduci-la dependencia da Misión das subvencións públicas: Gallástegui calculaba en 1930 que retendo 0'10 pesetas por kilo de semente vendido os ingresos poderían supoñer en pouco tempo 400.000 pesetas anuais ${ }^{41}$.

O SPS non se adicou somentes ó millo senón tamén á pataca, e ademais en novembro de 1932 creouse unha Sección de cría de cerdos Large-White (que incluía un sistema de seguros), cos que traballaba Miguel Odriozola, que formara unha cabana a partires do lote mercado en Inglaterra en febreiro de $1931^{42}$. A finais de 1935 comezáronse a da-los primeiros pasos cara á constitución dun Sindicato Provincial de Avicultores a requerimento da Asociación General de Avicultores de España e sobre todo de Ricardo de Escauriaza, o director da Granxa Agrícola, que tiña unha fe sen límites nos beneficios que acarrearían as industrias rurais

${ }^{40}$ Gallástegui expresou a súa opinión en termos moi enérxicos nun artigo sobre variedades de pataca en El Pueblo Gallego (15-X-1930) que foi impreso como cartel e tivo considerable difusión:

«Muchos agricultores y Sindicatos han pedido a la Misión Biológica direcciones de las casas productoras de estas variedades. A mi juicio no es este el camino que debemos seguir, dado lo bochornoso del comercio de semillas en España, excepción hecha de alguna que otra firma meritísima».

${ }^{41}$ EPG 10-IV-1930. Daniel de la Sota, presidente do Sindicato, botaba as contas da leiteira nunha entrevista que lle fixo no mesmo xornal X. Carballeira e calculaba que cando chegaran a proporcionar semente para a totalidade da superficie sementada de millo de Galicia, retendo 0'20 pesetas obterían 1.200.000 pesetas para o sostemento da Misión e o SPS (EPG 17-VII-1934).

${ }^{42}$ Para detalles, BSPS $n^{\circ} 1$ (II-1933), n 4 (1-V-1933) e nº 19 (II-1935). A aceptación desta raza foi moi boa, como exemplifica a decisión da sociedade agraria de Buxán de mercar dous exemplares como reproductores (ANT 6-IV-1935), e en El campo gallego, escrito en 1958, Gallástegui afirma que a absorción da raza do país estaba case completada, aínda que as pautas de alimentación aínda deixaban moito que desexar (GALLASTEGUI, 1958: 31).

"CUADERNOS DE ESTUDIOS GALLEGOS", Tomo XLIV, Fascículo 109, Santiago 1997. 
(tamén a cunicultura, apicultura...) e impulsara a formación dun Sindicato Avícola na provincia de A Coruña e a celebración dun Certamen anual no centro que dirixía ${ }^{43}$. O estoupido da guerra civil fixo inviable este proxecto, do mesmo xeito que variou por completo a actuación do Sindicato, pero isto xa rebasa os límites do período no que se enmarca esta investigación ${ }^{44}$.

A instauración do réxime republicano vai coincidir cun recoñecemento xeralizado da figura de Gallástegui, pois se en Galicia os galeguistas lle atribúen poderes case sobrenaturais, dende Madrid é reclamado para dous cargos de gran relevancia: a Inspección General del Fomento Pecuario primeiro, que Gallástegui se quitou de enriba en canto puido para volver á Misión ${ }^{45}$, e un posto no Consejo Ordenador de la Economía Nacional por decisión do Consello de Ministros en maio de 1932. Este organismo fora creado por un Decreto do 23 de abril, con funcións de asesoramento e consultivas, e tiña quince membros designados polo goberno polo seu prestixio profesional ${ }^{46}$.

En canto á súa actuación na recén creada —ante o escándalo dos enxeñeiros agrónomos-Dirección General de Ganadería, Juan Anto-

\footnotetext{
${ }^{43}$ Na sesión da Xunta Xeral Ordinaria do 6-XI-1935 do Sindicato, nomeouse unha comisión que redactase as bases para crea-lo Sindicato Avícola Provincial (BSPS nº 26, XI-XII 1935). Unha breve biografía de Escauriaza, a cargo de Lourenzo Fernández Prieto, en FRAGA VAZQUEZ e DOMINGUEZ (1993: 93-94). Sobre a súa actuación a partires de 1936 BERNARDEZ SOBREIRA (1994: 163). A potenciación das industrias rurais era un lugar común na prensa agraria católica de preguerra.

${ }^{44}$ O SPS foi suprimido en 1944 , o que supuxo un duro golpe para a Misión que sumar ás dificultades que caracterizaron esa década para tódolos centros de investigación galegos. Paradoxicamente, as sementes híbridas empregadas en España a partires dos anos cincuenta eran de procedencia francesa ou americana, por intereses comerciais, mentras algunhas das producidas na M.B. obtiñan un gran éxito en Francia (VVAA, 1985: 151).

${ }^{45}$ Gallástegui confésalle a López Suárez que non está interesado nese cargo en carta do 9-X-1931 (F.P.L.S.), case dous meses antes do nomeamento oficial.

${ }^{46}$ Un editorial de El Pueblo Gallego (24-III-1933) que aplaude a incorporación da Junta Consultiva de Aranceles y Valoraciones ó Consejo, pide ó mesmo tempo que Galicia teña un representante oficial como tal no mesmo que a protexa, por exemplo, dos prexuízos ocasionados polo proteccionismo cerealístico ou a entrada de carnes conxeladas. Gallástegui estaba presente a título persoal e «se encontró aplastado, desoído y hollado por el número de los que celaban otros intereses en pugna, y que, por eso, que no por la legitimidad de aquéllos, arrancaron siempre la parte del león».
}

"CUADERNOS DE ESTUDIOS GALLEGOS", Tomo XLIV, Fascículo 109, Santiago 1997. 
nio Tábara Delgado tense ocupado do tema (VVAA, 1985: 130). Un detalle dá idea do interese que tiña Gordón Ordás en incorporalo ó seu equipo de colaboradores: dado que Gallástegui carecía dos anos de exercicio profesional requeridos para o posto de Inspector Xeral do Fomento Pecuario houbo que emitir un Decreto especial (7-XII-1931) do Ministerio de Fomento para salvar tal impedimento. Gallástegui permanecería un ano nese cargo cun balance que o citado autor considera moi positivo na reorganización dos Servicios da nova Dirección Xeral ${ }^{47}$.

O arraigo da Misión ponse a proba en 1935, cando no contexto do axuste Chapaprieta anúnciase a retirada da subvención anual que recibía do Ministerio; daquela o ministro era nada menos que Martínez de Velasco, o líder do Partido Agrario. O artigo $5^{\circ}$ do Decreto (18-X-1935) suprimía por unha banda o Instituto de Investigaciones Agronómicas (unanimemente louvado por poñer orde nos servicios agronómicos e as bases para unha política investigadora a longo prazo), a cuarta parte dos Campos de Demostración e a quinta parte das Estacións e Centros (sen nomealos aínda), mentras no $8^{\circ}$ quedaba suprimida a subvención á Misión (que tiña orixe no decreto de 1929 que vimos anteriormente) $)^{48}$. Esta medida desencadeou mostras de solidariedade en varios xornais e partidos, e Basilio Alvarez dirixiu un rogo sobre a cuestión á Ministro o 12 de decembro ${ }^{49}$. En varios

${ }^{47}$ No exercicio dese cargo tomou parte na Conferencia da Carne, convocada polo Ministerio de Agricultura en novembro de 1932 e que elaborou unhas conclusións que non serían atendidas logo polo Executivo. Por outra banda, Gallástegui ocuparía a vicepresidencia da Real Sociedad de Historia Natural entre 1933 e 1934 e a súa presidencia en 1935, información que debo á amabilidade do Profesor Alberto Gomis Blanco.

${ }^{48} \mathrm{O}$ art. $9^{\circ}$ suprimía a Cátedra Ambulante de Agricultura e o art.12 facía o propio coas bolsas de estudios no estranxeiro para veterinarios e enxeñeiros agrónomos. Un editorial da revista Agricultura (nº 83, XI-1935) solicitaba a revisión dalgunhas destas medidas, en especial a supresión do Instituto de Investigacións Agronómicas pola descoordinación entre os diferentes centros que causaría, a da Cátedra Ambulante e a dos agregados Agronómicos das Embaixadas, pero non mencionaba en cambio á Misión. Para unha análise da Cátedra Ambulante en Galicia v. FERNANDEZ PRIETO (1988 bis), que a considera un precedente da Extensión Agraria. A Misión non participou nese Servicio, que se dirixía dende a Granxa Agrícola coruñesa.

${ }^{49}$ Tras facer un repaso dos logros da Misión pide que non se poña en perigo a continuidade dunha institución «que es, sin duda alguna, una de las poquísimas correspondencias que el Estado ha tenido para aquella región, sufrida y callada eternamente, que contribuye como la que más a las cargas del tesoro y que no recibe, sino gota a gota y muy de tarde en tarde, la ayuda presupuestaria».

"CUADERNOS DE ESTUDIOS GALLEGOS", Tomo XLIV, Fascículo 109, Santiago 1997. 
mitins de propaganda do Partido Galeguista vaise sacar a colación, en concreto por boca de Alexandre Bóveda e Víctor Casas, a retirada da subvención (ANT 15-XI e 22-XI-1935).

A Misión tratou de xoga-las súas cartas para que se dera marcha atrás á medida, e o seu Padroado acorda solicitar do Ministerio que nomee un Inspector que emita un informe sobre a conveniencia de suprimi-la subvención; o resultado será a Memoria de Marcelino de Arana y Franco -que involuntariamente lles fixo un gran favor ós historiadores pois proporciona gran número de datos-, que non só informou positivamente sobre a utilidade do centro senón que propuxo que se aumentara a subvención do Ministerio ata 65.000 pesetas e a da JAE en 15.000, para persoal adicional, e que se concederan 20.000 pesetas ó Sindicato de Productores de Semente para a construcción dun secadeiro de millo ${ }^{50}$. O Padroado reforzou este dictame sinalando as amplas perspectivas de futuro que se abrían ante a Misión, como eran a colaboración coa Estación de Mellora da Pataca creada había pouco tempo en Vitoria, retoma-los traballos sobre a «tinta» e afronta-los de pratenses e toxo dulce. Por tanto non só solicitaba a continuidade da subvención senón que se incrementase para dotar á plantilla doutro enxeñeiro agrónomo e de máis becarios en prácticas. Por último, o Padroado acorda porse en contacto con Rodríguez de Viguri, a quen a Misión xa debía algún favor de cando fora ministro de Economía, porque nas Cortes de 1933 fora elexido deputado por Lugo (como independente; logo incorporouse ó Partido Agrario Español) e precisamente estaba na Comisión de Presupostos. Estas xestións deron o seu froito porque finalmente a subvención non sería retirada, pero unha vez máis quedaba de manifesto que a dependencia dos diñeiros públicos supuña camiñar polo gume da navalla segundo sopraran os ventos na Administración ${ }^{51}$.

No traballo científico da Misión na súa etapa pontevedresa seguiu tendo o protagonismo o millo, que segundo Gallástegui non superaba en Galicia

\footnotetext{
${ }^{50}$ Libro de Actas, AMB, sesión do 28-XI-1935. Marcelino de Arana fora o primeiro director do Instituto de Cerealicultura e na revista Agricultura (nº 75 , III-1935) louvara o labor que estaba a realiza-la Misión na selección do millo.

${ }^{51}$ Nun artigo en La Voz de Galicia, Valeriano Villanueva criticou que se fixera tanto ruído por 50.000 pesetas cando a Reforma Agraria e as obras hidráulicas eran as que estaban a desviar millóns e millóns en beneficio doutras partes do Estado (VG 1-I-1936).
} 
uns rendementos medios de $2.000 \mathrm{~kg}$. por hectárea ${ }^{52}$. O Sindicato permitiu comproba-lo rendemento dos híbridos nas condicións da agricultura real, e non nas ideais dos centros de investigación. Unha idea que vai repetir Gallástegui unha e outra vez era que o incremento nos rendementos que proporcionaba o emprego de semente selecta só se plasmaba na realidade se as prácticas de cultivo e sobre todo o adubado eran os apropiados, porque a introducción de sementes híbridas debía se-lo revulsivo e ir acompañada dunha transformación dos hábitos de cultivo:

«No quisiera terminar estas cuartillas sin recordar aquí un dilema que me he puesto a mí más de una vez: Debemos elaborar una simiente de maíz que produzca máximas cosechas dentro de un cultivo de máxima intensidad o debemos seguir la ruta de proporcionar al labrador una variedad que se adapte mejor a su sistema de agricultura deficiente y esquilmada? No hay semilla que sirva para los dos usos a la vez. Hay que decidirse por una sola. Y en esta decisión en una región tan densamente poblada como Galicia creo que la contestación no tiene duda: Semilla de máximo rendimiento para una agricultura de máxima intensidad. Tal semilla es la doble híbrida, la que el Sindicato viene obteniendo ahora o la que podrá elaborar en el futuro, pero semilla doble híbrida al fin» ${ }^{53}$.

Das variedades de híbrido dobre as máis cultivadas foron a «Pepita de oro» (gran amarelo) e «Reina blanca» (gran branco); ORDAS (1992: 192), investigador da Misión Biolóxica a quen remito para unha aproximación ós aspectos estrictamente científicos do labor de Gallástegui co millo, destaca que na M.B. se buscaba proporcionar ó agricultor variedades o máis parecidas posibles ás autóctonas.

Sobre centeo ensaiáronse seis variedades alemanas en 1933-34 pero os resultados foron desastrosos, con menores rendementos que as variedades do país e maior vulnerabilidade ante as pragas (JUNTA PARA AMPLIACION DE ESTUDIOS, 1935: 382).

\footnotetext{
${ }^{52}$ Segundo BARREIRO GIL (1979), dos 65 traballos de Gallástegui que recopilou Antonio Odriozola, 20 estaban adicados ó millo e no resto case sempre ocupaba un lugar destacado.

${ }^{53}$ «Ventajas e inconvenientes de la semilla doble híbrida en relación con la semilla de variedades», BSPS n 16 (V-1934).
}

"CUADERNOS DE ESTUDIOS GALLEGOS", Tomo XLIV, Fascículo 109, Santiago 1997. 
Os estudios sobre as patacas víronse perxudicados pola inconstancia coa que se adicó a eles B.F.Osorio-Tafall, que era quen se encargaba deles cando llelo permitía a súa actividade política. O obxectivo era seleccionar variedades (que non obtelas novas) resistentes ás pragas, á dexeneración (finalmente comprobouse que se debía a viroses), ó «manchado» e ás xeadas sen merma da producción e da boa conservación, pero como Gallástegui era conscente de que o emprego de sementes selectas non sería suficiente e de que se requería unha transformación nos hábitos de cultivo, insertou no Boletín con frecuencia artigos divulgativos que complementaban así o labor dos centros coruñeses. Os ensaios comezaran en 1930 e ata 1934 comprobáranse 146 variedades procedentes principalmente de Alemaña pero tamén de Inglaterra, Holanda e Galicia ${ }^{54}$. Tratouse tamén de atopar zonas en Galicia onde a dexeneración fora mínima, o mesmo que ocurría en Escocia ou Pomerania, para producir nelas a semente de pataca para Galicia e España, evitando de paso a sangría monetaria e o risco de introducción de novas pragas que supuña a importación da mesma $^{55}$. Os directores da Estación de Fitopatoloxía (Urquijo Landaluce) e da Granxa Agrícola (Ricardo de Escauriaza) compartían estas prevencións, o mesmo que Valeriano Villanueva que falaba de abastecer a todo o Estado de pataca para sementar e que desaconsellaba importar variedades estranxeiras porque xa se probaran suficientes e podíaselle

${ }^{54}$ BSPS n ${ }^{\circ} 20$, III-1935. De tódolos xeitos na Memoria correspondiente a los cursos 1928-9 y 1929-30 da JAE faise mención a nove variedades ensaiadas ata 1929, pero o primeiro ensaio masivo produciuse en 1930 con 56 variedades traídas de Alemaña; segundo esa mesma fonte, os rendementos medios en Galicia oscilaban entre 12 e $15 \mathrm{Tm}$. por hectárea, mentras tres das variedades ensaiadas superaron as $50 \mathrm{Tm}$. (en cambio sete non pasaron das $10 \mathrm{Tm}$.). Varias delas eran variedades precoces, que sementadas a primeiros de marzo permitirían recoller antes do 25 de xullo ó redor de $15 \mathrm{Tm}$., o cal abriría interesantes perspectivas comerciais porque a súa cotización no mercado nesas datas era máis remuneradora.

${ }^{55}$ Osorio-Tafall: «Sobre las enfermedades de virus que atacan a las patatas cultivadas gallegas», en Anales de la Asociación Española para el Progreso de las Ciencias, $\mathrm{n}^{\circ} 2$, Ano III, 1936, pp.321-336. Un decreto do Ministerio de Economía do 7 de novembro de 1931 prohibiu as importacións de pataca de varios países (entre eles Francia, Alemaña e Polonia) para previ-la entrada da praga do escarabello ou Dorífora en España, o que deu aínda máis importancia ó labor do Sindicato de Productores de Semillas (EPG 10-XII1931). A devandita praga terminaría por introducirse na Península durante a Guerra Civil, ó desmantelarse o dispositivo organizado na fronteira con Francia.

"CUADERNOS DE ESTUDIOS GALLEGOS", Tomo XLIV, Fascículo 109, Santiago 1997. 
abri-la porta a novas pragas ${ }^{56}$.

É só a partires de 1935 que a Misión afronta seriamente os estudios sobre gando vacún, porque anteriormente o único que se fixera fora recopilar datos entre 1926 e 1930 aproveitando os concursos celebrados en Pontevedra sobre as posibilidades da raza galega como productora de leite e manteca. Precisamente foi de resultas das súas críticas que comezaron a varia-los baremos empregados, deixando de lado o aspecto exterior para centrarse na producción ${ }^{57}$.

En canto ó gando porcino, os estudios ían encamiñados por unha banda á mellora xenética da cabana mediante a introducción da raza LargeWhite e por outra á determinación das condicións nas que a cría resultaba rentable, que non eran en absoluto as tradicionais ${ }^{58}$. Os resultados levaron á conclusión de que o animal debía alcanzar os $100 \mathrm{~kg}$. de peso en medio ano e que o engorde a partir de aí era antieconómico (alcanzado o

${ }^{56}$ «Poco a poco los entusiastas importadores de lo exótico nos van trayendo todos los hongos dañinos de las patatas en las regiones frías de Europa, desconocidos antes en estas provincias. Sólo les falta importar el de la «sarna verrugosa» [o que non se produciu], tan terrible, y habrán completado la colección» (VG 17-XII-1932). En canto a Urquijo e Escauriaza, a postura do primeiro queda clara nunha conferencia publicada pola Deputación coruñesa en 1932 (divulgación $n^{\circ}$ 6) e a do segundo cando desaconsella as importacións de pataca alemana que se estaban a realizar durante a guerra civil porque a partir do primeiro ano baixaban moito os seus rendementos pero sobre todo pola posible propagación de andacios (CABO VILLAVERDE, 1994: 15).

${ }^{57}$ Sobre o labor de Gallástegui na gandería vacuna, vid. o artigo de Rafael Alenda en VVAA (1992), tomo I. Sobre os criterios que deberían adoptarse nos Concursos e Paradas, GALLASTEGUI (1979: 244). Como dato curioso, en 1935 o xerente da Nestlé en Santander visitou a Gallástegui para pedirlle consello sobre o emplazamento adecuado onde instala-la primeira fábrica de leite condensado en Galicia, recomendándolle o director da Misión Curtis ou ben Lalín (FPLS, carta 8-IV-1935), e efectivamente nesta última localidade construiuse unha planta de refrixeración que sería confiscada trala guerra e devolta en 1953.

${ }^{58}$ Xa nun artigo en 1930 afirma que a alimentación a base de patacas, fariña de millo, nabos e todo tipo de restos é antieconómica («es una hucha rota de la que gran parte del dinero que se guarda vuelve a salir por orificios ocultos»), EPG 23-VII-1930. A fórmula de alimentación que -con lixeiras variacións- propuña Gallástegui era a dun $70 \%$ de fariña de millo, un $20 \%$ de fariña de cacahuet, un $5 \%$ de fariña de peixe e outro $5 \%$ de fariña de carne. Por certo que no BSPS ( ${ }^{\circ} 26$, XI-XII 1935) se recomendaba a fariña de peixe elaborada pola fábrica Massó de Bueu -que se anunciaba no Boletín- tralos ensaios feitos con ela na Misión.

"CUADERNOS DE ESTUDIOS GALLEGOS", Tomo XLIV, Fascículo 109, Santiago 1997. 
centear de kilos facían falla catro unidades forraxeiras para gañar unha de peso vivo $)^{59}$.

As relacións da Misión cos outros centros de investigación agronómica existentes en Galicia nunca se desenvolveron a nivel institucional senón persoal, e de feito non se levaron a cabo investigacións conxuntas e non foron raros os casos de traballos paralelos sobre os mesmos temas sen colaboración oficial uns cos outros ${ }^{60}$. É o que Lourenzo FERNANDEZ PRIETO (1989: 22) ten denominado «asombrosa desconexión entre os centros que traballan en ciencias agrarias no país». Eso si, tanto Urquijo Landaluce como Luis Iglesias colaborarán en numerosas ocasións no Boletín do Sindicato, e o segundo dará algunhas conferencias na Misión.

Fornecidos xa cunha visión xeral da traxectoria da Misión e dos ámbitos nos que actuou, podemos xa pasar a unha valoración do esquema xeral no que se inscribían estas investigacións, o que Otero Pedrayo bautizou en 1932 no Parlamento como «Plan Gallástegui» atribuíndolle unha exhaustividade que seguramente non tiña («todos los problemas verdaderamente esenciales de Galicia están planteados y perfilados para una solución definitiva con la adopción de este plan») e poñendo nel unhas esperanzas que a creba de 1936 nos impide saber se eran excesivas («con él llegaría [Galicia] en pocos años a ponerse al tono que le corresponde dentro del mundo moderno») (GARCIA, 1978: 122).

${ }^{59}$ Memoria correspondiente a los cursos 1928-9 y 1929-30, JAE, páxina 283. Reafirmouse nesa tese nunha conferencia o 14 de maio de 1932 no Círculo das Artes de Lugo que non coñezo fora publicada (para unha reseña da mesma v. EPG 17-V-1932), e nunha conferencia pouco antes de morrer seguía poñendo nesa cantidade o umbral da rendabilidade (R.E.G., 1962: 123).

${ }^{60} \mathrm{~A}$ inexistencia de plans de investigación conxunta mantívose na postguerra entre os centros coruñeses e a Misión (CABO VILLAVERDE, 1994: 179), e paradoxicamente as relacións eran moito mais intensas con centros do resto do Estado ou do estranxeiro que cos doutras provincias galegas. O mesmo Gallástegui recoñece esta situación anómala en El campo gallego (GALLASTEGUI, 1958: 12).

"CUADERNOS DE ESTUDIOS GALLEGOS", Tomo XLIV, Fascículo 109, Santiago 1997. 


\section{A REFORMA DA AGRICULTURA GALEGA NOS ESCRITOS E NA OBRA DE CRUZ GALLASTEGUI.}

Gallástegui escribiu un número considerable de artigos en prensa antes de 1936 (a partir dese ano en moita menor medida), tamén foi autor de bastantes folletos e ponencias, e tres conferencias súas foron publicadas $^{61}$. Nos escritos ata mediados dos anos 20 predominan os de carácter estrictamente científico, a partir de aí os de divulgación do traballo realizado na Misión. O que non nos deixou Gallástegui foi unha obra máis ambiciosa onde expuxera a súa concepción xeral da nosa agricultura, trascendendo dos problemas concretos.

O que máis se asemella é El campo gallego, escrito en 1958, dous anos antes do seu pasamento, e cando xa se manifestaran os primeiros síntomas da enfermidade que habería rematar coa súa vida. Precisamente por esa circunstancia trátase máis ben dun esbozo ou notas para un libro que Gallástegui non chegaría a escribir, e presenta numerosas lagoas, pero aínda así resulta de gran utilidade e máis tendo en conta que a pesar do tempo transcurrido en liñas xerais é perfectamente coherente coas teses dos anos trinta, como en xeral todo o que seguiu escribindo a partir da guerra civil (sensación reforzada polo feito de seguir recurrindo en moitas ocasións ás estatísticas dos anos trinta por carecer doutras fiables para a postguerra). A partir destes materiais máis outros adicionais como entrevistas na prensa, a documentación da Misión e a correspondencia con López Suárez, reconstruiremos o plan xeral no que encaixaban e que daba sentido ós seus traballos á altura dos anos trinta, aínda que botaremos man tamén de escritos posteriores cando sexa necesario ${ }^{62}$.

Como é lóxico a reforma propugnada por Gallástegui encaixa perfectamente na categoría das técnicas, porque a súa principal preocupación son os aspectos productivos. Este carácter vai permitir que sexa asumida

\footnotetext{
${ }^{61}$ A recopilación máis completa da súa producción é a levada a cabo polo bibliotecario da Misión Antonio Odriozola; pode consultarse no Extraordinario da Revista de Economía de Galicia ${ }^{\circ} 25-30$ (1962, 142-144) ou ben na Revista Galega de Estudios Agrarios $\mathrm{n}^{\circ} 1(1979,227-252)$.

${ }^{62}$ Das entrevistas a maior parte realizóullelas coa súa habitual amenidade Xoán Carballeira en El Pueblo Gallego; galeguista e colaborador habitual tamén de A Nosa Terra, presidía a Comisión Xestora frentepopulista que rexía o Concello de Bueu o 18 de xullo e foi pasado polas armas.
}

"CUADERNOS DE ESTUDIOS GALLEGOS", Tomo XLIV, Fascículo 109, Santiago 1997. 
por un amplo espectro de forzas políticas, dende os galeguistas ós socialcatólicos, como veremos no seguinte apartado.

O punto de partida da proposta de futuro de Gallástegui era a intensificación de cultivos para facer viable o complexo policultivo-gandería tradicional e orientando cantos máis dos seus productos fora posible cara á comercialización, moi especialmente os gandeiros. Neste senso inscríbise na corrente maioritaria entre os técnicos de preguerra, pois entre todos eles rexeitábase unha especialización demasiado marcada debido á inseguridade que conlevaba nunha conxuntura tan inquedante como os anos da Depresión.

Un detalle, ou bastante máis que iso, no que Gallástegui polo contrario desentoaba con respecto ós citados, era na súa escasa fe na utilidade da introducción de novos cultivos para conquerir o mencionado obxectivo. Resulta revelador que na Misión non se experimente con ningún deles e de feito Gallástegui non os menciona sequera nos seus artigos e conferencias, a menos que por exemplo a remolacha fora implícita cando falaba das forraxeiras que ocuparían en parte o espacio deixado polo millo (en calquer caso nada que se pareza ó empeño posto primeiro por Hernández Robredo e logo por Escauriaza e Urquijo na sustitución do nabo pola remolacha $)^{63}$. O mesmo pódese dicir para o tabaco, sobre o que Urquijo Landaluce estaba a levar a cabo ensaios en colaboración co sindicalismo católico en vistas á súa introducción, en especial en rexións vitícolas para ofrecerlles alternativas ante a crise do sector ${ }^{64}$. Se ben Gallástegui en 1936 solicitou permiso para sementar terreos con tabaco (que non obtivo por retrasos burocráticos), amosábase moi escéptico, pois aínda que as condicións naturais eran propicias, o secado suporía grandes dificultades por non ter espacio o cultivador e aparte habería problemas polas diferentes calidades do tabaco de cada agricultor ${ }^{65}$. Deste cadro xeral podemos exceptua-la alfalfa, da que Gallástegui planexaba seleccionar variedades

${ }^{63}$ Sobre isto v. FERNANDEZ PRIETO (1988 bis: 415) e BERNARDEZ SOBREIRA (1995: 29) para Hernández Robredo e Escauriaza, e CABO VILLAVERDE (1994: 67) para Urquijo Landaluce.

${ }^{64}$ CABO VILLAVERDE (1994: 70); durante a guerra as autoridades franquistas potenciarían este cultivo para compensa-lo déficit do mesmo na España nacional (FERNANDEZ PRIETO, 1988-3).

${ }^{65}$ F.P.L.S., carta 7-VII-1936.

"CUADERNOS DE ESTUdIOS GALLEGOS", Tomo XLIV, Fascículo 109, Santiago 1997. 
adecuadas para Galicia para facilita-la especialización láctea, pero apenas fixo avances antes de que a guerra civil lle obrigara a deixar de lado esta liña de investigación (na que Hernández Robredo fixera na Granxa tímidas tentativas xa nos anos 10$)^{66}$.

A agricultura debía situarse, aínda máis do que xa o estaba, ó servicio da gandería; como se dicía no Boletín do Sindicato:

«Los cultivos predominantes en Galicia son los de maíz, patatas, y forrajes variados de raíces y hierbas, bien gramíneas bien leguminosas. - Todos, como se ve, tienden a la obtención de productos con los cuales mantener el ganado. - Quiere, por tanto, decir, que la agricultura gallega es, más que un fin, un medio de proveer la alimentación de la ganadería que sostiene» (BSPS n 19, II-1935).

O millo era o portaestandarte e a pedra de toque da intensificación, debido tanto á súa importancia no complexo agrario galego como a se-lo vexetal máis axeitado para a aplicación das técnicas xenéticas coas que Gallástegui se familiarizara en EEUU. De feito moita xente tomou a parte polo todo e para moitos o director da Misión convertiuse no «mago dos millos», esquecendo o resto do labor desenvolvido no Centro ${ }^{67}$. En data tan temperá como 1924 Gallástegui xa enuncia a ecuación que permitiría introduci-los cambios no senso desexado: partindo duns índices de producción moi baixos por hectárea (que nese momento cifra en $1.250 \mathrm{Kg} . /$ ha. e logo -influído seguramente polo traslado a Pontevedra- eleva ata case as dúas toneladas), a introducción de sementes híbridas e a mellora nas pautas de cultivo permitirían a reducción da superficie ocupada polo millo (200.000 ha. nas que se obtiñan $250.000 \mathrm{Tm}$.) sen que menguase a producción ou incluso aumentándoa, deixando terreo libre para adicalo a forraxes e prados artificiais que sostivesen unha cabana gandeira en crecemento (GALLASTEGUI UNAMUNO, 1924).

${ }^{66}$ Para esto último, FERNANDEZ PRIETO (1988 bis: 416). Moitos anos despois, Gallástegui mantén a mesma actitude con respecto ás posibilidades dos novos cultivos (lúpulo, tabaco) ou da recuperación doutros desaparecidos como o liño (GALLASTEGUI UNAMUNO, 1958: 22).

${ }^{67}$ Non é de extrañar cando o mesmo Gallástegui afirmaba categoricamente: «[...] más maíz y menos tierra. todo el secreto del mejoramiento agropecuario de Galicia, primeramente, radica ahí: en aumentar la producción de maíz por hectárea» (EPG 19-VII-1933).

"CUADERNOS DE ESTUDIOS GALLEGOS", Tomo XLIV, Fascículo 109, Santiago 1997. 
Por tanto a solución estaría en conseguir incrementa-los rendementos digamos ata as catro ou cinco toneladas por hectárea para conseguir que o cultivo do millo deixara de ser antieconómico, e nunca na súa eliminación:

«El problema es algo más difícil y no se resuelve declarando al maíz el destierro. La patata, la vid, y otros vegetales, que a veces se citan para suplantarle, son inciertos, muy inciertos en sus producciones en nuestro clima y en ningún caso y bajo ningún concepto serán sustituto de nuestro cereal» ${ }^{68}$.

Na peliaguda cuestión da libre importación do millo, Gallástegui sostiña contra a corrente maioritaria no agrarismo que sería perxudicial. Na súa coñecida conferencia Esbozo de programa agrario para Galicia, pronunciada en Vigo o 3 de decembro de 1930 baixo os auspicios do «Grupo Autonomista Galego», expón o seu razoamento con claridade: Galicia producía anualmente entre 250.000 e $300.000 \mathrm{Tm}$. de gran, importando 8.000-10.000 Tm. en anos bos e en anos malos 20.-25.000 Tm., que equivalían a un 5\% da producción. En cambio o Estado no seu conxunto producía 550.000-600.000 Tm., véndose forzado a importar unhas 200.000 máis (equivalentes ó 83\% do total da producción de España sen Galicia). De permitirse a libre importación os grandes beneficiarios serían os productores do resto do Estado, que estarían en condicións de obter carne en mellores condicións que os galegos e máis perto dos mercados (GALLASTEGUI UNAMUNO, 1979: 240). De non autorizarse, a situa-

${ }^{68}$ GALLASTEGUI UNAMUNO, 1927. Peña Novo é un exemplo dos que identificaban millo e atraso, e cando nun traballo de 1918 quere louva-lo alto grado de desenvolvemento agrícola da bisbarra betanceira sinala o pouco peso do millo e en xeral dos cereais, en beneficio dos productos hortícolas (ROCA CENDAN, 1986). Moito máis tarde, Castelao recolle esta tese — que ampara citando a Rof Codina-, e destaca de paso que o que impide levala á práctica é o odiado arancel imposto polos trigueiros (SG: 416). Xa falando para todo o Norte peninsular, nos órgano de prensa dos veterinarios presaxiábase a sustitución de tódolos cereais por forraxeiras, incluído o millo por non ser capaz de competir co arxentino; calculábase que unha hectarea sementada de millo proporcionaba en valor en metálico menos da metade doutra con remolacha forraxeira, que ademais tiña maior valor nutritivo (Publicaciones de la Dirección General de Ganadería e Industrias Derivadas, IV-1933: 125-137).

"CUADERNOS DE ESTUDIOS GALLEGOS", Tomo XLIV, Fascículo 109, Santiago 1997. 
ción existente nos anos trinta, onde máis acuciante se fai a carestía é no resto de España, que cos seus altos prezos desvía hacia elas a producción galega e así trasládase o problema de xeito indirecto á nosa terra porque nela comeza a escasear tamén o cereal.

A importación de millo non é para Gallástegui máis que unha solución aparente, e a verdadeira é o incremento dos rendementos medios mediante a xeralización das súas sementes. Por eso cando ante a que parecía inminente e inevitable ratificación do Convenio co Uruguai (que suporía facilidades para a entrada de carne conxelada dese país) empezou a reclamarse como compensación a libre importación de millo, Gallástegui opúxose en varias entrevistas, repetindo que o que se pretendía compensación non era en realidade senón un dobre dano (EPG 18-VII-1933). As razóns serían o seu carácter incompleto como alimento do gando pola súa falta de proteínas, que o campesiño galego non podía baixa-lo prezo do gando, que vendía xa moi por debaixo dos custes de producción (1'5 e catro pesetas/Kg. respectivamente), e por último que Galicia xa estaba moi perto de autoabastecerse de millo e como media no período 1922-32 importara só $6.000 \mathrm{Tm}$. anuais ${ }^{69}$.

A comezos de 1936 Gallástegui proclama alcanzado ese obxectivo cos datos dos dous anos anteriores na man (EPG 1-I-1936). En 1934 a colleita fórase ata os 355.900 toneladas , mentras que Galicia non consumía máis de 330.000 Tm. ó ano, o cal permitíralle exportar a Asturias, Santander e Bilbao. E sen embargo seguírase coa teima pola introducción do millo con dereitos reducidos, e cando finalmente se autorizou, do cupo permitido Galicia importou menos do $1 \%$ (por Vigo; e por enriba logo reexportouse a Asturias), o cal en opinión do Director da Misión daba unha absoluta sensación de informalidade.

Coa guerra civil e as circunstancias da postguerra o reloxio deu marcha atrás, e atopamos os mesmos obxectivos dos anos vinte e trinta, de novo proclamados como metas a conquerir como se no interín non pasara nada. Por eso na ponencia que presenta Gallástegui ó Congreso Agrícola de Galicia de 1944 volvemos encontrar cálculos que nos remiten ós de

${ }^{69}$ EPG 19-VII-1933 e GSA VIII-1933. Con todo, Gallástegui era perfectamente conscente de que de concede-lo goberno a libre importación de millo (á que se opuñan os intereses trigueiros) o destino da Misión sería do máis incerto, como confesa en carta a López Suárez con data 14-X-1928 (F.P.L.S.).

"CUADERNOS DE ESTUDIOS GALLEGOS", Tomo XLIV, Fascículo 109, Santiago 1997. 
dúas décadas atrás ${ }^{70}$. Máis descorazonador aínda, se cabe, resulta a grandilocuente proclamación nos medios sindicais dunha «batalla del maíz» de resonancias mussolinianas para a provincia de A Coruña nada menos que en 1953 para comezar a extende-los millos dobres híbridos, que para máis inri son de procedencia americana ${ }^{71}$.

A definitiva integración do sector agrario galego na economía de mercado basearíase segundo Gallástegui no gando (principalmente o vacún), como viña sucedendo dende bastantes décadas atrás. Dende a crise finisecular desenvolvéranse en Galicia as dúas polémicas interrelacionadas de se debía primarse a especialización láctea ou cárnica, e en función dos caracteres que se quixera primar se na mellora gandeira había que optar pola importación de razas estranxeiras ou pola selección das autóctonas ${ }^{72}$.

Gallástegui vai entrar no debate pronunciándose pola selección da raza rubia (coincidindo con Rof Codina) como base da mellora gandeira, e pola reorientación cara á especialización láctea, unha opinión que a caída continua dos prezos da carne de vacún da década dos vinte convertira en maioritaria ${ }^{73}$. De aí os controles leiteiros que a Misión levou a cabo nos concursos organizados pola Deputación pontevedresa entre 1926 e 1930

${ }^{70}$ GALLASTEGUI UNAMUNO, 1944. Por certo que nesa ponencia Gallástegui vese obrigado a recurrir a estatísticas dos anos trinta dada a inexistencia ou escasa fiabilidade das dos anos corenta. Do citado Congreso, que Gallástegui viu como unha carga de traballo máis resolta nunha fanfarria triunfalista sen consecuencias prácticas (F.P.L.S. carta a López Suárez 5-X-1944) sairía o Plan Agrícola de Galicia, o proxecto de insertarnos no modelo autárquico que está analizado con todo detalle en BERNARDEZ SOBREIRA (1995).

${ }^{71}$ El Noroeste $\mathrm{n}^{\circ} 15,21-\mathrm{VIII}-1953$.

${ }^{72}$ Para a descripción destas teses, FERNANDEZ PRIETO (1992: 267) e BERNARDEZ SOBREIRA (1995: 49-56), extendéndose este último como é lóxico tamén sobre o acaecido na postguerra.

${ }^{73}$ Gallástegui en 1927 (citado en VVAA, 1985: 117):

«Es una realidad, que la producción láctea media de vaca controlada, cuando se alimenta bien, llega a ser hasta de 3.000 litros entre dos partos, y ello sin acudir a piensos de ninguna clase, como sería necesario en las razas extranjeras, lo cual demuestra bien a las claras que la raza gallega es digna de tenerse en cuenta como animal lechero, sobre todo en relación con su rusticidad y mediano tamaño, características en las que pocas razas le aventajan».

Nunha conferencia en Lugo en 1932 declara non ser partidario de importar vacas do estranxeiro porque aínda que as crías producto do cruce coas do país teñan un máis precoz desarrollo, tamén requiren máis e mellor alimentación (EPG 17-V-1932).

"CUADERNOS DE ESTUDIOS GALLEGOS", Tomo XLIV, Fascículo 109, Santiago 1997. 
e os seus intentos (que hoxendía a ciencia sabe infructuosos) por obter liñas puras mediante selección e cruzamentos como facía, mutatis mutandis, cos millos ${ }^{74}$. Gallástegui expón con toda claridade a súa posición nun texto non excesivamente coñecido, falamos da Memoria que escribiu como membro do Consejo Ordenador de la Economía Nacional fundamentando o Decreto de 23 de novembro de 1934 que regulaba a venta de manteiga e margarina ${ }^{75}$. Nese informe desenvolve, como fixo noutras ocasións, a súa distinción entre países de agricultura e gandería extensivas (Arxentina, Uruguai ou Australia pero tamén Andalucía, A Mancha e Extremadura) que teñen como orientación natural a cárnica, e países de cultivo intensivo onde a producción de carne resulta antieconómica, todo o contrario que a láctea (Holanda, Suíza, Dinamarca, Galicia, Asturias, Santander). Para Gallástegui o Estado debe favorecer que esa dicotomía adquira perfís nítidos en España. Noutras ocasións fala de gandería «africana» (pastoreo - Sur de España) e «europea» (Galicia).

Esa orientación láctea tiña unha importante vantaxe engadida: era máis propicia que a cárnica para o xurdimento de industrias agroalimentarias, mentras a segunda non deixaba de ser unha exportación en bruto de recursos primarios (algo atemperada no caso de existir Matadoiros nos puntos de orixe). O modelo ideal nesto, como para tantos outros, serían Dinamarca e Holanda, a referencia case universal nos medios técnicos e agraristas de preguerra.

Resulta interesante sinalar que o director da Estación Pecuaria de Lugo, Juan Carballal Palmeiro, compartía as teses de Gallástegui neste particular, e isto tiña que marca-la orientación do centro que dirixía. Segundo os seus cálculos, en 1932, producir un Kg. de carne de terneira, que valía 3' 40 pesetas, requería 20 litros de leite, que acadaban un valor no mercado de 20 pesetas, o cal deixaba claro o camiño a seguir, se ben como Gallástegui non propugnaba o abandono da producción e exportación de carne senón o seu relegamento a un segundo plano (EPG 5-X-1932).

${ }^{74}$ VVAA, 1992: 372. En carta a López Suárez de 9-XI-1927 Gallástegui afirma que «De criar ganado para engorde soy pesimista. Los precios están muy bajos y aunque suban algo durante el invierno volverán a bajar en la primavera. Yo creo que Andalucía y sobre todo Extremadura deben criar ya bastante ganado y hacen competencia a las carnes gallegas. Creo que en Galicia debemos ir cada vez más a la leche [...]» (F.P.L.S.).

${ }^{75}$ A Memoria pódese consultar no F.P.L.S.

"CUADERNOS DE ESTUDIOS GALLEGOS", Tomo XLIV, Fascículo 109, Santiago 1997. 
A reorientación gandeira no senso sinalado requería de cambios paralelos nos cultivos. Confiar exclusivamente nos prados como propuñan algúns xulgábao Gallástegui imposible por condicionantes naturais: o solo arenoso (que retiña pouca auga) e a sequía estival. Ademais os prados permanentes «supondrían una rémora en una región superpoblada como la nuestra» (R.E.G., 1962: 124), sendo preferibles os prados temporais de trevo (rico en proteínas) intercalados nas rotacións en forma de prados bianuais.

A inserción nos circuitos de comercialización non sería exclusiva do gando vacún, reservándose un importante papel nela ó porcino, o que requería unha transformación racial e de patróns de alimentación que farían posible as investigacións de Miguel Odriozola ${ }^{76}$. A explotación do porcino podería combinarse á perfección coa láctea alimentando ós lechóns co leite desnatado que constituiría un dos subproductos das mantequerías, facilitando unha carne de menor calidade que a dos porcos de máis idade pero a menor precio e por tanto capaz de supli-la insuficiencia de consumo de carne na dieta de amplas capas da poboación (GSA VIII-1933).

$A$ avicultura e as pequenas industrias rurais en xeral xogaban claramente un papel subsidiario no seu esquema, aínda que se coidaba de sinalar que a Estación Pecuaria (creada en Lugo en 1931) debería incluír entre os seus comentidos a selección de razas por medio da adquisición dos exemplares máis destacados nos Concursos que se organizaran (EPG 25VII-1931).

O monte mantería por unha banda o seu papel tradicional de proporcionador de toxo co que fabrica-lo esterco, e por outro intensificaría a súa dimensión forestal, e aquí o piñeiro tería total protagonismo en detrimento do carballo e do castiñeiro (malia toda a atención posta nesta última árbore en distintos períodos na Misión), e só o eucalipto podería prosperar á súa sombra ${ }^{77}$. Esta explotación forestal, protagonizada por Deputacións e Concellos en consorcio co Estado, serviría para dar orixe a

\footnotetext{
${ }^{76}$ De tódolos xeitos a raza autóctona ou celta non debía diluírse completamente nos Large White e debía ser preservada porque «se ignora [...] si en las aldeas del interior donde la alimentación del cerdo se practica a base de sustancias voluminosas como nabos, patatas, etc.- daría iguales resultados» (GALLASTEGUI UNAMUNO, 1979: 245).

${ }^{77}$ GALLASTEGUI UNAMUNO, 1958: 52, e 1962:118.
}

"CUADERNOS DE ESTUDIOS GALLEGOS", Tomo XLIV, Fascículo 109, Santiago 1997. 
unha industria do papel e a fábricas de celulosas, e de novo atopamos aquí os recursos naturais de Galicia como soporte da industria propia que se anceiaba e que permitiría desviar poboación activa dende o sector primario ó secundario (EPG 25-V-1935). Eso si, a repoboación coas especies citadas debería facerse en harmonía cos usos tradicionais do monte ${ }^{78}$.

A concentración parcelaria era para Gallástegui unha necesidade para soslaia-los inconvenientes da dispersión das parcelas, mediante o intercambio entre propietarios (EPG 24-V-1935) ${ }^{79}$. Gallástegui, coincidindo plenamente co programa galeguista, non concibe outra cousa que non sexan as pequenas propiedades, pero purificadas dos seus excesos ata chegar a explotacións familiares («la propiedad ha de estar limitada a la producción necesaria para el mantenimiento de una familia viviendo exclusivamente de la tierra»- EPG 24-V-1935). Como primeiro paso, debía prohibirse por lei toda ulterior subdivisión por herencia do terrazgo.

O motor das transformacións sería o dobre empuxe do cooperativismo por unha banda e a acción do Estado pola outra. O cooperativismo aparece como a única vía posible nunha rexión de pequena propiedade, e cooperativos debían se-los Matadeiros, cooperativa a organización dos productores de porcino e os gandeiros que proporcionasen o leite ás mantequerías e queserías tamén se organizarían cooperativamente. O cooperativismo sería un fin en si mesmo, non un estadío transicional cara a fórmulas colectivistas como ocurría no caso dos socialistas (EPG 25-V1935). De feito Gallástegui emprega a expresión «comunidad cooperativa» (GSA VII-1933: 696) para referirse a Galicia, definición que coincide literalmente coa empregada no programa oficial do Partido Galeguista. Tras unha viaxe a Italia en 1934 volve entusiasmado polos progresos que en materia agraria se están a producir baixo o réxime feixista e acaricia a idea de crear un Consorcio de productores de leite en Galicia como o existente por exemplo en Milán, que garantiría a salubridade do leite (EPG 13-VII-1934). A organización en cooperativas multiplicaría a difusión das novidades científicas no agro e tamén poría ós agricultores a salvo de

\footnotetext{
${ }^{78}$ Gallástegui dá neste particular a impresión de querer contentar a todo o mundo e conciliar intereses contrapostos, e o feito de non respaldar con cifras os seus razonamentos acentúa esa sensación.

${ }^{79}$ Máis tarde engadiría ós perxuicios ocasionados polo minifundio o de dificulta-la mecanización dos labores agrícolas (GALLASTEGUI UNAMUNO, 1958: 28)
}

"CUADERNOS DE ESTUDIOS GALLEGOS", Tomo XLIV, Fascículo 109, Santiago 1997. 
comerciantes pouco escrupulosos en cuestión de adubos, sementes, etc. Deste xeito non resulta difícil de comprende-lo empeño que pon Gallástegui en que se atope unha solución non traumática para o Matadoiro de Porriño, de xeito que non tivese un efecto disuasorio ou desmobilizador sobre o ánimo asociativo dos labregos, e que acepte que a M.B. se involucre na xestión do mesmo segundo a solución artellada polo ministro de Agricultura do bienio azañista, Marcelino Domingo.

En canto á acción do Estado, o outro motor da transformación, Gallástegui semella decantarse por un Estado forte e activo que financie e promova a concentración parcelaria, asuma os custes da definitiva redención foral, sosteña unha completa rede de centros de investigación e ensinanza agrícolas, etc ${ }^{80}$. De feito, á volta de Italia chega a afirmar que o cooperativismo por si só é inútil se antes non se afronta unha Reforma Agraria que no caso galego consistiría principalmente na concentración parcelaria e a intensificación de cultivos ${ }^{81}$. O Estado que anceia Gallástegui non é o indolente da Restauración senón outro máis pegado á realidade cotiá (aquí a autonomía sería inexcusable) e que deixara en mans dos técnicos a dirección da política agraria, como ocorría na Italia feixista. Os límites da presencia estatal non quedan moi claros (¿fixación de prezos de taxa, compra de excedentes?) pero parecen rebasar amplamente o que serían simplemente medidas de fomento e estímulo do sector primario, como se desprende dos eloxios ós Consorcios de productores de leite e a municipalización dos mercados de legumes na Italia de Mussolini (EPG 13-VIII-1934). E sen embargo recela Gallástegui dun protagonismo ex-

${ }^{80}$ Para o plan de organización dos servicios agronómicos que diseñou xunto con Juan López Suárez v. FERNANDEZ PRIETO (1992: 144) ou directamente GALLASTEGUI UNAMUNO (1979). Resumindo, creación dunha Estación Enolóxica en Ourense, unha de Praticultura en Lugo e outra de Fruticultura e Horticultura na Coruña, restablecemento da Estación de Fitopatoloxía (suprimida en 1929), desaparición das Seccións Agronómicas provinciais e creación dun Padroado que dirixira estes centros (e maila M.B. por suposto) e se encargara da planificación a longo prazo e constituído por personalidades non ligadas á política agás un representante por cada Deputación. Este proxecto foi aplaudido en EPG (15-X-1933) e A Fouce n ${ }^{\circ} 53$ (15-VIII-1932: 1).

${ }^{81}$ EPG 13-VII-1934; un aspecto no que Gallástegui apenas pasou das vaguedades foi o crédito agrícola, máis alá da constatación da necesidade da súa reforma para a implantación real das novidades (GALLASTEGUI UNAMUNO, 1979: 239).

"CUADERNOS DE ESTUDIOS GALLEGOS", Tomo XLIV, Fascículo 109, Santiago 1997. 
clusivo do Estado ${ }^{82}$, case tanto como o fai da empresa privada, sempre proclive a abusos e enganos movida polo afán de lucro. A solución por tanto radicaría na combinación do impulso da sociedade organizada en cooperativas, coa actuación estatal.

Para que o Estado fose quen de cumpli-las misións asignadas a autonomía constituíase en paso previo imprescindible:

« Cada problema, grande o pequeño que a Galicia se le presente [...] confirma que esta región es una unidad económica, una comunidad cooperativa, en realidad un pueblo autónomo. Que lo sea políticamente, para encarar profundamente sus problemas, es la más viva necesidad. Los que nieguen esto o no saben nada, o no se cuidan de pensar en serio sobre estas cosas, o proceden de mala fe» (GSA VII1933: 696).

E Gallástegui chega en ocasións incluso a emplaza-la consecución da autonomía como a condición previa necesaria para a plasmación do seu plan de transformacións, xusto na liña dos galeguistas ou dos editoriais de El Pueblo Gallego

«Primero y ante todo partamos de esta necesidad: autonomía. Sin ella todo será baldío, solución de segunda mano, y por ello, opuesto a la realidad viva de la región gallega. Ese es el básico -y único- punto de vista que debe interesar a los gallegos hoy para llegar lo más lejos posible» ${ }^{83}$.

${ }^{82}$ Por exemplo en «Orientaciones sociales en la organización de la mejora de plantas» (BSPS n 17-18, VI-VII-1934), afirma que de encargarse en exclusiva o Estado da distribución da semente selecta se caería no emprego dun número excesivamente reducido de variedades, que serían introducidas en zonas para as que non serían adecuadas. Tras considera-las posibilidades existentes, Gallástegui recoñece máis vantaxes á combinación do Estado con cooperativas ou no seu caso con empresas privadas, como fai él co S.P.S., en Suecia a Estación de Svalof ou en Alemaña o Instituto de Xenética de Munchenberg (Berlin).

${ }^{83}$ EPG 24-V-1935. En aberta contradicción con estas manifestacións públicas en favor da autonomía (e con outras que mencionaremos no seguinte apartado), nunha carta a López Suárez (F.P.L.S.) poucos días antes do plebiscito de xuño de 1936 Gallástegui fai referencia ó « [...] Estatuto gallego que desgraciadamente vendrá», o cal quizais debe interpretarse como froito dun posible desagrado por vir o mesmo da man do Fronte Popular e de monopoliza-los partidos de esquerda o movemento pro-Estatuto (Gallástegui pertencía á fracción máis conservadora dentro do universo galeguista).

"CUADERNOS DE ESTUDIOS GALLEGOS", Tomo XLIV, Fascículo 109, Santiago 1997. 
Sobre os peares da autonomía e o cooperativismo articula pois Gallástegui a súa proposta de reforma agraria técnica para Galicia, pero antes de rematar botemos unha ollada ós aspectos chamemos «sociais», ós que o director da Misión fixo referencia en bastantes ocasións durante os anos trinta. No que se refire ó foro, Gallástegui pronúnciase pola redención por conta do Estado, facendo abstracción do delicado estado das finanzas públicas ${ }^{84}$. O Estado adiantaría os cartos mediante unha Caixa de Crédito Foral e logo, eso si, recuperaría unha parte deles a medida que o dominio útil fora amortizando o préstamo inicial sen interese (a quince ou vinte anos) ou ben mediante unha contribución foral por tempo limitado (EPG 25-VII-1931 e 24-V-1935). Como no caso do Partido Galeguista, quedaban a salvo os intereses dos propietarios e descartada absolutamente calquera solución abolicionista ${ }^{85}$. Como tantos outros, Gallástegui louva a función histórica do foro, que serviría para poñer en cultivo grandes extensións de terreo e garantir ó labrego unha cuasi-propiedade, e culpa ó subforo da súa dexeneración (GALLASTEGUI UNAMUNO, 1962: 119). Aínda que apenas fai mención ó arrendo, éste parece quedar reducido a un papel totalmente marxinal en comparación coas pequenas explotacións familiares que constituirían a base da Galicia comunidade cooperativa que vai trazando nas súas conferencias e colaboracións de prensa durante os anos da República. De ser certo este posicionamento contra o arrendamento, a súa postura sería máis radical neste punto que a do Partido Galeguista (tinxida de ambigüidades e en conxunto máis atenta ós intereses dos propietarios), pero a inexistencia de referencias máis detalladas por parte de Gallástegui impide afirmalo categoricamente.

\footnotetext{
${ }^{84}$ Para a cuestión foral durante a II República vid. o capítulo cuarto de CABO VILLAVERDE (1995).

${ }^{85}$ « [...] es especie generada que todos los que cobran foros son individuos acomodados, mientras se da el caso de que la mayor parte de los foreros son campesinos mismos, que perciben una pequeñísima renta» (EPG 24-V-1935).
}

"CUADERNOS DE ESTUDIOS GALLEGOS", Tomo XLIV, Fascículo 109, Santiago 1997. 


\section{O PLAN GALlASTEGUI: APOIOS, APROPIACIONS E CRI- TICAS.}

Para introducir este apartado, e a pesares da lonxitude da cita, gostaríame botar man da evocación que fai Castelao da Galicia coa que soñaba nun futuro imprevisible. Vaia pois, sen intención haxiográfica, porque non é pouca a conexión co que estamos a tratar nestas páxinas:

«Vexo casas limpas e hixiénicas, de feitura paisán e d-acor do coas comenencias da vida labrega e mariñeira.

Vexo os montes repovoados e cobertos de piñeiraes. Vexo grandes fábricas de pasta de papel e de productos derivados do leite.

Vexo Centros de investigación e de esperimentación agropecuaria. Vexo piscifactorías, Laboratorios costeiros i Escolas de pesca.

Vexo â Universidade de Sant-Iago convertida en cerebro de Galiza, irradiando cultura e saber, máis alá dos lindeiros naturaes da nosa Terra. Vexo Escolas ruraes de formación campesiña, para soerguer a comunidade aldeán.

[...] Vexo Sindicatos productores de semente, rexidos por xenetistas experimentados. Vexo pazos para albergar as Cooperativas, mellores que en Dinamarca.

Vexo enormes criadeiros de mariscos. Vexo o trafego d-un gran porto pesqueiro - o máis importante de Europa-. Vexo cangar barcos con peras urracas e mazáns tabardillas.

Vexo, en fin, unha Terra farturenta, onde todos traballan e viven en paz. Vexo a miña Terra como unha soia cibdade, a cibdade-xardín máis fermosa do mundo, a cibdade ideal para os homes que queiran vivir a carón da Natureza.

Así soñábamos Bóveda e máis eu nos días de espranza. Así sigo soñando eu, pol-os dous, â veira do Mediterráneo, este mar que non comprendo...» (SG: 134).

As referencias a Gallástegui non poden ser máis evidentes, o que tentaremos averiguar será ata qué punto se produciu a apropiación das súas propostas polos galeguistas e se foi tan forte que deu lugar a reaccións de rexeitamento entre as outras forzas políticas galegas.

"CUADERNOS DE ESTUDIOS GALLEGOS", Tomo XLIV, Fascículo 109, Santiago 1997. 
Gallástegui proporciona ó P.G. o manto perfecto de respectabilidade e empaque científico co que recubri-lo seu programa agrario ${ }^{86}$, e a Misión Biolóxica vai desempeñar unha triple función na práctica política e propaganda galeguistas:

1- Proba da viabilidade da autonomía, a máxima aspiración do partido nos anos trinta, contrapoñéndoa á ineficacia dos servicios agronómicos dependentes do Estado ${ }^{87}$. Na Asemblea de Concellos de Santiago de decembro de 1932 Alexandre Bóveda non dubida en poñela como modelo do que será a actuación do futuro goberno autónomo galego, pois fai moito máis cunhas cen mil pesetas anuais que os servicios estatais con catro veces esa cantidade (CORES, 1986: 54), e o mesmo fai Villar Ponte nas súas colaboracións en prensa ${ }^{88}$.

2- Demostra-la cegueira do centralismo, que en varias ocasións está a piques de obrigar a pecha-la Misión a pesar do potencial que encerraban as súas investigacións. Esta función queda patente nos carteis de propaganda do plebiscito de xuño de 1936, onde se emprega o intento de supresión da subvención á Misión do ano anterior como argumento contra o centralismo. Xa antes Suárez Picallo denunciara que malia o que xa eran

${ }^{86}$ No Sempre en Galiza hai tres páxinas nas que Castelao non fai outra cousa que reproducir case palabra por palabra os razonamentos e cifras do Esbozo de programa agrario para Galicia, en concreto cando fala de que a experimentación debe preceder á ensinanza («pol-o de agora un labrego galego sabe moitísimo máis de agricultura galega que un eminente profesor formado fora de Galicia»), o crédito e a remodelación dos Servicios Agronómicos (SG: 130-32).

${ }^{87}$ É o que fai Filgueira Valverde nunha conferencia en Lugo en xuño de 1936, na que aparte de a Tafall e Gallástegui pon de exemplo de técnico comprometido con Galicia a Urquijo Landaluce, vasco e próximo ó social-catolicismo, que dirixía a Estación de Fitopatoloxía da Coruña, esta si dependente do Ministerio de Agricultura ( $L a$ Voz de la Verdad, 19-VI-1936).

${ }^{88}$ «[...] obsérvese cómo la Misión Biológica de Pontevedra y el Sindicato de Productores de Semillas, instituciones netamente regionales aun sin todo el apoyo preciso realizaron en el poco tiempo que llevan de vida una labor de extensión que seguramente es la primera de España. ¿Por qué?

Porque la técnica no constituye el punto de mayor importancia, puesto que la técnica es cosa segura, no falla; lo esencial resulta la psicología, la manera de ser y de vivir de las gentes de los diversos países, a cuyos factores hay que amoldar toda actuación [...] Y como dijo muy bien Gallástegui, una organización de fomento agropecuario que se pueda publicar desde la «Gaceta» no es aplicable a todas las regiones» (VILLAR PONTE, 1971: 93).

"CUADERNOS DE ESTUDIOS GALLEGOS", Tomo XLIV, Fascículo 109, Santiago 1997. 
realidades palpables do labor da Misión, «el Estado no la ha subvencionado como era debido, porque siempre que se refiere a cosas de nuestra región, el Estado no las conoce» (GARCIA, 1978: 359).

3- Fortalece-la confianza dos galegos en si mesmos e a súa fe nas súas posibilidades de acadar maior prosperidade polos seus propios medios. Os primeiros en interiorizar esa convicción foron os mesmos galeguistas, que en ocasións atribuían a Gallástegui poderes case taumatúrxicos, véxase senón a Suárez Picallo nas Cortes Constituíntes o 12 de xaneiro de 1932 con ocasión da enésima petición da libre importación do millo confiando en que «Puede que de hoy en un año Galicia no tenga que plantear esta cuestión, porque tenemos ahora una Misión Biológica que está encargada de los trabajos conducentes a triplicar, si es posible, nuestra producción maicera» ${ }^{89}$.

Os galeguistas organizan campañas de prensa con ocasión de cada ataque que sufre a Misión, como cando o traslado de Gallástegui a Madrid ou sobre todo a supresión das 50.000 pesetas de subvención do Ministerio ${ }^{90}$.

Non todo quedaba en declaracións, varios grupos galeguistas locais (como os de Vilagarcía e Ourense) van levar a cabo exposicións e repartos das sementes da Misión e organizar excursións a Salcedo ${ }^{91}$. O prestixio do centro e do seu modelo de organización semiautónomo era tal que cando se pide dende Rianxo a creación dunha institución de estudio da pesca galega se fala dunha «Misión Biolóxica do Mar» (ANT 13-VII1935). Incluso en ocasións ó final dun mitin político galeguista organízase

${ }^{89}$ GARCIA, 1978: 199; Antón Villar Ponte pensaba que as teses de Gallástegui demostraban as «enormes» posibilidades dunha Galicia autónoma (6-II-1932)

${ }^{90}$ A campaña para que Gallástegui se reintegrase a Galicia animárona El Pueblo Gallego e Castelao, e por iniciativa deste último trinta dos corenta e sete parlamentarios galegos se comprometeron a face-las xestións pertinentes («Nadie ignora que esta Institución representa para Galicia la más fuerte garantía de su resurgimiento agrícola y ganadero») e obter das Deputacións que lle paguen un soldo como Xefe dos Servicios de Fomento Pecuario de Galicia para que non teña que abandoa-la Misión. (EPG 24-I1932).

${ }^{91}$ Por exemplo ANT 1-II-1932 e II-V-1935; en convencer ós grupos galeguistas e sociedades dos beneficios desa tarea de divulgación puxo especial empeño Xoán Suárez Picallo, corresponsal para Sada de ANT e EPG, irmán do deputado e asasinado polos golpistas a pouco do comezo da guerra.

"CUADERNOS DE ESTUDIOS GALLEGOS", Tomo XLIV, Fascículo 109, Santiago 1997. 
unha mostra dos productos da Misión para dalos a coñecer entre a concurrencia, e os oradores glosan o labor de Gallástegui de maneira que ós asistentes non lles quedaría moi clara ónde estaba a raia separadora entre a M.B. e o Partido Galeguista ${ }^{92}$.

A clave estaba seguramente en que os plans do director da Misión non fondo non supuñan un replantexamento radical do complexo agrario galego senón unha potenciación do mesmo e unha maior orientación cara ó mercado pero respetando as súas características esenciais (policultivo, explotación familiar...), e incluía nas súas receitas puntos básicos do programa do P.G. como o cooperativismo ou a autonomía.

O mesmo apoio incondicional mostrou cara a Gallástegui El Pueblo Gallego, tanto nos seus editoriais como por boca dos seus comentaristas en temas agrarios, como Xoán Carballeira ou Anxel de Cambeses, para quen era «como una lotería no esperada» ${ }^{93}$. $\mathrm{O}$ curioso é que os editoriais do xornal vigués empregan incluso ó propio Gallástegui para xustificar posturas contrarias ás defendidas polo director da Misión. Verbigracia, o seu nome aparece invocado nada menos que para defende-la libre importación de millo, e non unha vez senón varias. Así, no «Opiniones» do 13V-1934 («O no pueden entendernos o no quieren») afírmase que é partidario de sustituír o millo por forraxeiras e cubri-las necesidades deste cereal mediante importacións de Sudamérica, e o mesmo no titulado «Las relaciones comerciales con la Argentina» do 13 de decembro dese ano.

O grao de identificación, salvando estas discordancias, queda de manifesto con toda claridade na portada do 25 de xullo de 1931, cando a esquerda da mesma está ocupada por un editorial coas reivindicacións políticas que defende o xornal (sobre todo e ante todo a autonomía) e á dereita aparece en forma de columna un artigo de Gallástegui no que expón as súas principais teses.

${ }^{92}$ Por exemplo un mitin en Viascón (Cotobade) de Núñez Búa, Suárez Picallo e Castelao, ó remate do cal o primeiro explicou as vantaxes dos millos seleccionados por Gallástegui coa axuda de gráficos.

${ }^{93}$ EPG 31-I-1932; e tamén nada menos «el que fundamentalmente sacará a Galicia de su sueño letárgico para aplicarlo al porvenir del campesino» (EPG 19-II-1932). Para X. Carballeira podemos citar entre outros os artigos con data EPG 18-VI-1933, 26-I-1934 e 28-IV-1934 (é o primeiro de falar da necesidade dunha «batalla do millo»). Asimesmo, o director do xornal, Portela Valladares, louva a Gallástegui nunha entrevista en 1932 e xustifica cos seus estudios o potencial económico de Galicia (VG 22-IV-1932).

"CUADERNOS DE ESTUDIOS GALLEGOS", Tomo XLIV, Fascículo 109, Santiago 1997. 
Os que daban o salto ata o arredismo, en concreto estou a falar da Sociedade Nazonalista Pondal de Buenos Aires e o seu órgano A Fouce, en realidade sacaban proveito da existencia da Misión nas súas mensaxes con funcións similares ás que acabamos de ver, aínda que en moitas menos ocasións. Reclaman por exemplo a publicación dunha revista adicada a temas agropecuarios financiada polas sociedades agrarias e que podería ser dirixida polo propio Gallástegui (AF I-1934).

Os católicos semellan compartir a confianza en Gallástegui pero sen exteriorizalo tanto e sen pasar das declaracións formais, porque non se dá a consigna por exemplo ás Federacións de difundir sobre unha base regular os experimentos da Misión ${ }^{94}$. Eso si, «O fillo d'un labrego», un dos principais comentaristas de Galicia Social Agraria, non só louva as sementes da Misión senón que comparte os plans do seu director de prima-la orientación gandeira en Galicia e intensifica-la producción de millo para non depender das aleatorias importacións de Arxentina (GSA n ${ }^{\circ}$ 21, III-1932). A esto debemos engadirlle que os parlamentarios conservadores tomaron parte nas sucesivas campañas en defensa da Misión, como foi o caso tamén do radical Alfredo García Ramos ${ }^{95}$.

Aparte dese último caso, as personalidades do Partido Radical que amosaron publicamente o seu apoio á Misión foron Basilio Alvarez (con declaracións pero tamén con feitos como vimos anteriormente) e secundariamente o deputado por Ourense Luis Fábrega Coello (VG 18-V-1932).

\footnotetext{
${ }^{94}$ Galicia Agraria menciona en 1928 que algún sindicato quere experimentar cos millos da Misión trala reportaxe aparecida previamente nesa revista pero non temos probas de que ese interese se traducise nalgo serio (GA n 29, 15-III-1928). No número seguinte aclárase que a Misión atende primeiro os pedidos procedentes das outras tres provincias porque a coruñesa é xustamente a única Deputación que non colabora no sostemento do centro, pasividade que lle reprocha o editorial da revista (GA ${ }^{\circ}$ 30, 1-IV1928). O único caso que coñecemos, e non sabemos se tería continuidade ou non, é o do sindicato católico de Muros que por mediación de GA conseguiu $22 \mathrm{Kg}$. de semente seleccionada da Misión (GA nº 31, 15-IV-1928).

${ }^{95}$ Neste caso concreto antes de ser elexido para o Parlamento e nas páxinas de $E l$ Faro de Vigo: «La Misión Biológica» (6-III-1931) e «La economía rural gallega. Botón de muestra» (13-I-1932). Foi tamén García Ramos quen deu a idea no citado xornal (6XI-1932) de revitaliza-lo cultivo do liño en Galicia, recollida axiña pola Sociedad Económica de Amigos del País de Santiago, que pediu a Gallástegui que realizara ensaios, que polo que sei non se levaron a cabo, pero en todo caso resulta significativo que se recurrira a el e non á Granxa da Coruña (EC 31-I-1933).
}

"CUADERNOS DE ESTUDIOS GALLEGOS", Tomo XLIV, Fascículo 109, Santiago 1997. 
Dos orguistas o deputado pola Coruña Ramón María Tenreiro (VG 2-IV1932) e como é lóxico Osorio-Tafall nos seus discursos parlamentarios, están no mesmo caso.

Entre os agraristas Gallástegui goza de boa reputación e moitas esperanzas, a veces desbordadas, púñanse nos seus estudios, pero bótase en falla, aínda que houbera casos, que máis sociedades deran o paso cara a unha colaboración continuada e sobre bases sólidas coa Misión e o Sindicato de Sementes. O director da M.B. chegou a ser proposto pola Federación Agraria de Lavadores como candidato a deputado nas Cortes Constituíntes, ofrecemento que naturalmente foi rexeitado. A Federación Agraria Provincial tiña claras simpatías pola obra da Misión e varios dos seus líderes como Indalecio Tizón, M.Aldecoa ou Antón Alonso Ríos así o demostran en varias ocasións ${ }^{96}$.

Entre quen non atopamos mencións (nin tampouco as sinalan as monografías sobre o tema) é entre os socialistas galegos, quizais pola súa preferencia por enfoques máis sociais (por exemplo co tema dos arrendamentos) e menos técnicos nas cuestións agrarias.

En todo caso, e aínda que como vemos os galeguistas trataron - moi lexitimamente por outra banda- de converter en algo propio a Misión, non chegaron a tal grado de apropiación que provocasen reaccións de rexeitamento entre o resto do espectro político. Isto ven facilitado pola condición de técnico, e por tanto supostamente aséptico e á marxe de politiqueos, de Gallástegui, o mesmo fenómeno que explicaría que técnicos de tódalas tendencias colaborasen en prensa agrarista tamén de diversa orientación. Quen sabe se o enorme prestixio profesional de Gallástegui non tería promovido en torno súa un consenso sobre o modelo de desenvolvemento agropecuario que conviña para Galicia entre as distintas forzas (cooperativismo, intensificación de cultivos, orientación láctea, etc.), pero iso non pasa de ser unha hipótese máis ou menos atractiva.

Vimos a actitude do Partido Galeguista con respecto a Gallástegui, pero agora imos facer á inversa, coñece-lo grao de compromiso do vasco co partido que o ensalzaba e o axitaba como bandeira política. O primeiro

${ }^{96}$ I. Tizón nun mitin na Parroquia de Leiro (EPG 27-V-1932), M. Aldecoa en EPG 27-VIII-1933) e Antón Alonso Ríos pon a Gallástegui como exemplo de técnico comprometido en EPG 2-VII-1935.

"CUADERNOS DE ESTUDIOS GALLEGOS", Tomo XLIV, Fascículo 109, Santiago 1997. 
dato que temos é que Gallástegui forma parte como conselleiro da directiva de Labor Galeguista de Pontevedra, un dos grupos (este con predominio da tendencia máis dereitista dentro do galeguismo) que xurdiron co novo réxime e que confluirían en decembro dese ano no $\mathrm{PG}^{97}$. Gallástegui está presente precisamente na Asemblea fundacional en Pontevedra e interviu ademais na discusión sobre a postura do partido nacente sobre a importación de millo (acordándose finalmente pedi-la libre importación mentras a producción propia non cubrise as necesidades de consumo) (CASTRO, 1985, vol. I: 122). É ocioso precisar que o director da Misión tiña carnet de afiliado ó partido, circunstancia que se fixo pública en $A$ Nosa Terra en máis dunha ocasión. Tamén se podería sinalar aquí a amizade que lle unía a Alexandre Bóveda, que traballou algún tempo como contable-administrativo na Misión ${ }^{98}$.

En canto á súa vinculación co ideal autonomista, está presente en actos pro-Estatuto, como un banquete de homenaxe a Osorio-Tafall e Bóveda que por certo fora precedido por unha visita á Misión (EPG 4-I-1933). Xa antes R. López Pol, alcalde de Santiago e presidente da Comisión Organizadora da Asemblea de Concellos de Galicia, invitara a Gallástegui a asistir á mesma, pero excusóuse aducindo unha viaxe por Andalucía e Extremadura por obrigacións do seu cargo de Inspector Xeral de Hixiene Pecuaria ${ }^{99}$. A principios de 1933 asina un Manifesto de profesionais de distintas ramas a favor do Estatuto elaborado pola Asemblea de Concellos no que se asegura que o texto estatutario non é nin de dereitas nin de esquerdas; outros firmantes son o catedrático de Bioloxía Luis Iglesias

${ }^{97}$ O presidente era José García Vidal, membro como vimos do Padroado da Misión, secretario José Filgueira Valverde, tesoureiro Claudio Losada Prada e conselleiros aparte de Gallástegui Castelao e Xerardo Alvarez Limeses. A súa finalidade sería « [...] contribuir o robustecimento da concencia colectiva de Galicia, pol-a difusión dos estudos galegos, e a propaganda das nosas realidades, traballando no espallamento da cultura, no inzamento da lingua e no melloramento da economía». (EPG 1-V-1931).

${ }^{98}$ Gallástegui na correspondencia con López Suárez amosa ás claras as súas simpatías por Bóveda e o respeto que lle merece o seu traballo, e se mostra indignado polas represalias políticas de que é obxecto (F.P.L.S.: 28-IV-1930, 6-III-1931 e 27-X-1934). Dos desterros encubertos de Bóveda e Castelao en 1934 afirma que son unha vinganza política de Emiliano Iglesias. Sen embargo en ningún momento alude á ideoloxía ou militancia de Bóveda nin a ningún outro galeguista.

${ }^{99}$ I.P.S., Caixa 1, carta dende Madrid con data 24-VI-1932.

"CUADERNOS DE ESTUDIOS GALLEGOS", Tomo XLIV, Fascículo 109, Santiago 1997. 
Iglesias, García Vidal, Jacobo Varela de Limia, Alvarez Limeses, Pérez Constanti, Salustiano Portela Pazos, Alvaro de las Casas, ..., como se ve en efecto xente de diversas tendencias ${ }^{100}$. A istas mostras de compromiso hai que sumarlle o posicionamiento público que fai en artigos e conferencias e que comprobamos no apartado anterior.

A vinculación co Partido Galeguista foi o bastante clara como para que os seus inimigos tentaran facer uso dela na conxuntura de 1936, con graves acusacións na prensa falanxista que obrigan a Gallástegui a redactar para presentar ante o Padroado en xaneiro de 1937 un informe sobre a «inactividade política» do centro durante o período republicano ${ }^{101}$. Para rebati-la denuncia Gallástegui repasa un por un os compoñentes do persoal da Misión, comezando por el, que «jamás perteneció ni tuvo contacto con partido político alguno», e seguindo por Miguel Odriozola (que se presentara voluntario no requeté) e Ramón Blanco, que fora asignado á M.B. por orde do Comandante Militar de Pontevedra. O seguinte párrafo paga a pena reproducilo porque nel está condensado o esforzo por negar tres veces a Cristo (mil veces xustificado naquelas circunstancias):

«Pudiera por último inducir a error -o interpretarse terriblemente- el hecho de haberse utilizado por algún partido político regional alguna o algunas de las conclusiones económico-agrícolas, obtenidas y publicadas por dicho Centro. Las conclusiones generales del cultivo de la patata en Galicia han sido, por ejemplo, recogidas con fines políticos en algún caso.

A la vista de estos antecedentes, no es de extrañar que el personal técnico de esta Misión, cree que, por fortuna, el problema planteado no en sino la prosecución de una ya vieja rivalidad de orden profesional, entre determinados elementos difíciles de contentarse y el Director de la Misión Biolóxica de Galicia.»

Como se ve non esaxera quen afirme que os enxeñeiros agrónomos acolleron con recelos a creación da Misión, pero eso xa se sae do tema deste traballo e tentaremos acometelo noutras investigacións futuras.

\footnotetext{
${ }^{100}$ CASTRO (1985: 607 e nota 269).

${ }^{101}$ Sobre este tema vid. para tódolos centros galegos BERNARDEZ SOBREIRA E CABO VILLAVERDE (1995).
}

"CUADERNOS DE ESTUDIOS GALLEGOS", Tomo XLIV, Fascículo 109, Santiago 1997. 
Se Gallástegui se limitara a defende-lo apoliticismo dos investigadores do centro que dirixía aínda podía convencer a quen tiña que convencer, pero a maiores trata de facer pasar polo aro da neutralidade e a dedicación exclusiva ás súas tarefas científicas á totalidade dos membros do Padroado ( $\ll$ Puedo asegurar que tampoco ninguno de sus componentes particularmente ha tenido la menor intervención [política]»). Se dicimos isto é pola presencia no mesmo, en calidade de Secretario, de Bibiano Fernández Osorio-Tafall, que durante a República fora deputado (elexido en 1931 e 1936), alcalde de Pontevedra, presidente da Asemblea de Concellos de decembro de 1932 que elaborou o Estatuto de Autonomía, subsecretario do Ministerio de Gobernación con Casares cando estoupa o Alzamento e nos momentos en que Gallástegui escribe ese informe director da revista oficial de Izquierda Republicana Política e Presidente da Sociedade de Amigos da Unión Soviética ${ }^{102}$.

A pesar do «curriculum» de Tafall Gallástegui non sufriu represalias, quizais porque as acusacións non ían para aquél senón contra o mesmo Gallástegui («yo, contra quien van los tiros»). Sen embargo, o feito de que os seus inimigos trataran de aproveita-la súa vinculación ó Partido Galeguista pode mostrar que tal era a impresión reinante, que é o que queríamos dilucidar aquí e ó que apuntan tódolos indicios que fun presentando. En todo caso a Misión atravesaría enormes dificultades en tódolos ordes durante a guerra e a década dos corenta (BERNARDEZ SOBREIRA e CABO VILLAVERDE, 1995).

Antes de rematar este capítulo, faremos mención a aqueles que se amosaron publicamente críticos co labor da Misión, que en realidade non son máis que dous casos.

O primeiro deles é Ricardo de Escauriaza y del Valle, o enxeñeirodirector da Granxa Agrícola da Coruña entre 1928 e 1952. Os desacordos con Gallástegui restrínxense a cuestións profesionais ou técnicas, en concreto a inadecuación dos seus híbridos de millo ás condicións da provincia coruñesa, pero non se amplían á súa concepción da orientación xeral a seguir en cuestións agropecuarias (de feito Escauriaza potenciará por

\footnotetext{
${ }^{102}$ AMB. Libro de Actas do Padroado. Tafall foi designado Secretario na sesión do 7 de marzo de 1935. A única biografía de Tafall é a de ALVAREZ (1992). Antes de rematala guerra desempeñaría o cargo de Comisario Xeral de Guerra da zona gubernamental.
}

"CUADERNOS DE ESTUDIOS GALLEGOS", Tomo XLIV, Fascículo 109, Santiago 1997. 
exemplo na Granxa a especialización láctea) nin políticas. Aínda sen mencionar explicitamente a Gallástegui ou á Misión, Escauriaza nega a validez dos seus híbridos para A Coruña nun artigo na revista Agricultura (IX-1935: 581-84):

«Los híbridos Pepita de Oro y Reina Blanca [os máis comúns dos producidos na M.B., o primeiro de gran marelo e o segundo de gran branco], de los que tanta propaganda se ha hecho, no dan resultados constantes en esta provincia [...]. Por su largo período vegetativo, si el verano es fresco y húmedo no maduran bien, y, si es seco, necesitan del riego, lo que no es corriente aquí. Por su gran desarrollo, son fácilmente abatidos por el viento; sus largas mazorcas quedan en gran parte de la punta al descubierto, lo que acarrea su rápido enmohecimiento; sus largos pedúnculos hacen que las mazorcas desciendan hacia el suelo, durmiendo sobre ellas las aguas y recibiendo la humedad de éste, lo que también contribuye a enmohecerlas. Por último, su gran exigencia en abono, así como el sistema de cultivo que se aconseja y el elevado precio a que se vende su semilla, recargan extraordinariamente los gastos de cultivo. Estas son las causas por las que no se han extendido en la provincia, lo que no quita para que en el Centro y Sur de España estén dando excelentes resultados».

Escauriaza oponlle ós híbridos da Misión os producidos polo centro que el dirixe, en especial o híbrido (obtido a partir da selección do maíz do país) Coruña ${ }^{103}$. Da tirantez das relacións dos enxeñeiros da Granxa con Gallástegui dá idea un artigo de Pelay Asín (Agregado ás ordes de Escauriaza) en Galicia Social Agraria titulado «El cultivo del maíz en Galicia» no que non menciona nin unha vez a Misión, e eso que a metade do mesmo está adicado ás variedades de millo existentes (GSA V-1934: 851-854). Pelay limítase a recomenda-las variedades producidas na Granxa (Pioner White de ciclo corto, Coruña) e se fala da Pepita de Oro e a Reina Blanca é para dicir que o seu longo ciclo vexetativo e a súa esixencia en adubos fan o seu cultivo antieconómico agás nos vales de Pontevedra e Sur de Coruña.

${ }^{103} \mathrm{O}$ mesmo artigo apareceu logo en forma de folleto divulgativo editado pola Deputación Provincial da Coruña en 1935 e en Galicia Social Agraria (Nº 64, X-1935).

"CUADERNOS DE ESTUDIOS GALLEGOS", Tomo XLIV, Fascículo 109, Santiago 1997. 
Xa durante a guerra civil Escauriaza, a quen as autoridades militares lle van encargar unha serie de informes cos que orienta-la súa política agraria e de abastecementos, redobla as súas críticas ós híbridos da Misión cos mesmos argumentos que vimos anteriormente ${ }^{104}$.

Se nestas críticas tiñan o seu peso as disputas corporativistas, non se pode dici-lo mesmo das formuladas por Valeriano Villanueva, que non era enxeñeiro agrónomo senón militar e xurista e ademais por estes anos xa estaba xubilado e a súa única actividade pública eran os artigos que periodicamente firmaba en $\mathrm{La} \mathrm{Voz}$ de Galicia ${ }^{105}$. Nun primer momento amósase entusiasmado pola obra de Gallástegui, súmase á homenaxe que se preparou cando o trasladaron a Madrid (e que finalmente non se celebrou a petición do propio homenaxeado) e asegura que experimentará cos híbridos na súa propia finca, aínda que para a súa extensión ve como un obstáculo difícil de superar a carestía e escasa fiabilidade dos adubos (VG 4-II-1932). A intensificación do cultivo do millo permitiría poñer fin ó inútil «lloriqueo» dos políticos galegos en vistas a obte-la importación de millo con dereitos aduaneiros reducidos (VG 14-II-1932). Aínda en xullo de 1933 defende a Gallástegui e denuncia que os políticos galegos tralo aparente interese e «oratoria fácil y de lirismos» que lle adicaran agora esqueceranse del (VG 5-VII-1933).

O xiro na valoración que de Gallástegui fai V. Villanueva prodúcese a partir de outono de 1933, cando deixando a salvo as súas sementes pasa a critica-los seus «rematadamente indoctos» plans de desenvolvemento agropecuario (VG 28-X-1933). Nun artigo posterior ironiza dicindo que tras case dez anos de propaganda dos millos híbridos da Misión, nin 20 hectáreas se sementaban con eles ó ano en Galicia ${ }^{106}$. Coincide no fundamental coas críticas de Escauriaza (aínda que non o cita) e di que polos coidados que requiren os híbridos da Misión son verdadeiros cultivos de horta e supoñen empeza-la casa polo tellado (VG 24-II-1935 e 7-III-1935).

\footnotetext{
${ }^{104}$ ACIAM, carpeta «Planes de trabajo y presupuestos»: «Estación Experimental de La Coruña: Plan de trabajos de investigación para el año agrícola 1936-37».

${ }^{105}$ Deste autor DURAN (1984) ten editado unha antoloxía comentada.

${ }^{106}$ VG 4-XI-1934. Fai reflexionar a constatación de que na mesma parroquia de Salcedo a principios dos anos 60 en menos dun 10\% da superficie sementada con millo se empregaban dobres híbridos (CASTELO TETTAMANCY, 1964: 44).
}

"CUADERNOS DE ESTUDIOS GALLEGOS", Tomo XLIV, Fascículo 109, Santiago 1997. 
En resume, $\mathrm{o}$ «Plan Gallástegui» que os galeguistas presentaban como a verdadeira Reforma Agraria que necesitaba Galicia (xunto cunha nova lexislación dos arrendamentos e a protección legal da pequena propiedade), en oposición á elaborada en Madrid, atopou bastantes apoios máis alá do P.G. e no peor dos casos indiferencia, que non apenas oposición. Isto podería terlle garantido as circunstancias máis favorables para o seu desenvolvemento nunha Galicia autónoma, pero como tantas outras cousas isto non pasa de ser un de tantos «¿e que tería pasado si...?» xerados polo 18 de xullo.

\section{BIBLIOGRAFIA CITADA}

ALVAREZ, S. (1992). Osorio-Tafall. Su personalidad, su aportación a la historia, Ediciós do Castro, Sada.

BARREIRO GIL, X. (1979). «D. Cruz Gallástegui Unamuno (1891-1960). O seu labor en prol da mellora da agricultura de Galicia», Revista Galega de Estudios Agrarios, n², pp.269-277.

BERNARDEZ SOBREIRA, A. (1995). O Plan Agrícola de Galicia. Intervencionismo estatal e propostas de desenvolvemento agrario no primeiro franquismo (1939-1955), tese de licenciatura (inédita), Universidade de Santiago.

BERNARDEZ SOBREIRA, A. e CABO VILLAVERDE, M. (1995). «Paisaxe despois dunha batalla: a investigación agropecuaria en Galicia durante a guerra civil e os anos corenta», ponencia presentada ó $V$ Simposio de Historia e Ensino das Ciencias, Vigo.

CABO VILLAVERDE, M. (1994). A Estación de Fitopatoloxía Agrícola de A Coruña (1926-1951), tese de licenciatura (inédita), Universidade de Santiago.

CABO VILLAVERDE, M. (1995). Alen do latifundio: Galicia e a Reforma Agraria da II República, traballo de $3^{\circ}$ ciclo (inédito), Departamento Historia II, Facultade de Xeografía e Historia, USC.

"CUADERNOS DE ESTUDIOS GALLEGOS", Tomo XLIV, Fascículo 109, Santiago 1997. 
CABO VILLAVERDE, M. (no prelo). «Reducindo incertidumes: A Estación de Fitopatoloxía de A Coruña (1926-1972) e a súa incidencia na agricultura galega», Ingenium, $\mathrm{n}^{\circ} 5$.

CASTELAO, A.D. (1994). Sempre en Galiza, Akal editor, Arealonga, tomo 2 da Obra Completa, $4^{a}$ edición, Madrid.

CASTELO TETTAMANCY, Mª C. (1964). «Situación económica del Ayuntamiento actual de Pontevedra en el siglo XVIII y comparación con el XX», Revista de Economía de Galicia, nº41-42, pp.34-49.

CASTRO, X. (1985). O galeguismo na encrucillada republicana, Deputación Provincial de Ourense, 2 vol.

CORES TRASMONTE, B. (1986). Las polémicas de Bóveda en la gestación del Estatuto de Autonomía, Ediciós do Castro, Sada.

DURAN, J.A. (ed.) (1984). Valeriano Villanueva: Organización del cultivo y de la sociedad agraria en Galicia y en la España Atlántica, Xunta de Galicia (Consellería de Presidencia) e MAPA, Madrid.

FERNANDEZ DE ANA MAGAN, F.J., LOPEZ OVIEDO, J.M. E RODRIGUEZ-FERNANDEZ, R.J. (1995). «Historia do coñecemento sobor das doenzas do castiñeiro en Galicia», ponencia presentada ó V Simposio de Historia e Ensino das Ciencias, Vigo.

FERNANDEZ PRIETO, L. (1988). A Granxa Agrícola-Experimental da Coruña, 1888-1928, Xunta de Galicia, Santiago.

FERNANDEZ PRIETO, L. (1988 bis). «Estado e sociedade no proceso de renovacion tecnolóxica da agricultura galega, 1900-1936» en VILLARES, R. (ed) (1988), Donos de seu. Estudios de Historia Agraria de Galicia, Barcelona, pp.349-420.

FERNANDEZ PRIETO, L. (1988 -3). «Agricultura, ganadería e economía de guerra: Novas orientacións de política agropecuaria para Galicia, 1936-1939», Grial, nº100, pp.233-246.

"CUADERNOS DE ESTUDIOS GALLEGOS", Tomo XLIV, Fascículo 109, Santiago 1997. 
FERNANDEZ PRIETO, L. (1989). «Infraestructura e organización da investigación agropecuaria en Galicia durante o primeiro tercio do século XX», Ingenium, ${ }^{\circ} 1$, pp.11-25.

FERNANDEZ PRIETO, L. (1992). Labregos con ciencia, Ed.Xerais, Vigo.

FRAGA VAZQUEZ, X.A. e DOMINGUEZ, A. (coords.) (1993). Diccionario histórico das ciencias e das técnicas de Galicia. Autores, 1868-1936, Ediciós do Castro, Sada.

GARCIA, X.L. (1978). Castelao, Otero Pedrayo, Suárez Picallo, Villar Ponte: Discursos parlamentarios (1931-1933), Castro, Sada.

HERVES SAYAR, E. (1991). Agrarismo e societarismo campesiño no val do Tea, 1900-1936, Tese de Licenciatura inédita, USC.

ORDAS, A. (1992). «Perspectiva histórica de los maíces híbridos en Galicia», en VV.AA.: IOO anos de investigación agraria (1888-1988), tomo II, Xunta de Galicia, pp.189-209.

PAZ ANDRADE, V. (1982). Castelao na luz e na sombra, Ediciós do Castro, Sada (A Coruña).

PORTO UCHA, A.S. (1986). La Institución Libre de Enseñanza en Galicia, Ed. do Castro, A Coruña.

PRIMER CONGRESO DE ECONOMIA GALLEGA. Ed.Facsímil (1991), Ediciós do Castro, Sada.

ROCA CENDAN, M. (1986). «Do sector agrario en Betanzos no primeiro tercio do século XX», Anuario Brigantino, n9, pp.71-75.

RODRIGUEZ GARCIA, M. (1994). Historia da Escola de Veterinaria de Santiago (1882-1924), Universidade de Santiago (Servicio de Publicacións e Intercambio Científico).

VILLAR PONTE, A. (1971). Pensamento e sementeira. Leciós de patriotismo galego, Edicións do Centro Galego de Buenos Aires, Instituto Argentino de Cultura Gallega.

"CUADERNOS DE ESTUdIOS GALLEGOS", Tomo XLIV, Fascículo 109, Santiago 1997. 
VV.AA. (1985). Homenaje a Cruz Gallástegui Unamuno, Deputación de Pontevedra.

VV.AA. (1992). 100 anos de investigación agraria (1888-1988), Xunta de Galicia.

\section{BIBLIOGRAFIA DE EPOCA. FONTES IMPRESAS.}

BLANCO, R. (1925). Apuntes sobre la enfermedad del castaño, Lugo.

ESCAURIAZA Y DEL VALLE, R. (1935). Instrucciones para el cultivo del maíz, Deputación Provincial de A Coruña.

GALLASTEGUI UNAMUNO, C. (1924). Cómo se debe hacer la selección en el maíz, Consejo Provincial de Fomento de Lugo.

GALLASTEGUI UNAMUNO, C. (1927). Métodos para aumentar las producciones de maíz («Conferencia pronunciada con motivo de la celebración del Tercer Concurso Provincial de Ganados, organizado por la Diputación»), Deputación de Pontevedra.

GALLASTEGUI UNAMUNO, C. (1944). Mejora de los rendimientos económicos del cultivo del maíz. Medios para aplicar la acción de la Misión Biológica de Galicia a todo el campo gallego, Ponencia Provincial $\mathrm{n}^{\circ} 11$, C.A.G.

GALLASTEGUI UNAMUNO, C. (1958). «Las posibilidades de la economía agrícola y ganadera de Galicia», Revista de Economía de Galicia, $\mathrm{n}^{\circ} 1$ (Xaneiro-febreiro 1958), pp.40-48.

GALLASTEGUI UNAMUNO, C. (1958). El campo gallego, Editorial Citania, Buenos Aires.

GALLASTEGUI UNAMUNO, C. (1979). «Esbozo de programa agrario para Galicia», reproducido na Revista Galega de Estudios Agrarios, $\mathrm{n}^{\circ} 1, \mathrm{pp} .225 .252$.

"CUADERNOS DE ESTUDIOS GALLEGOS", Tomo XLIV, Fascículo 109, Santiago 1997. 
JUNTA PARA AMPLIACION DE ESTUDIOS E INVESTIGACIONES CIENTIFICAS (1933). Memoria correspondiente a los cursos 1931 y 1932, Madrid.

JUNTA PARA AMPLIACION DE ESTUDIOS E INVESTIGACIONES CIENTIFICAS (1935). Memoria correspondiente a los cursos 1933 y 1934, Madrid.

\section{ABREVIATURAS}

1. Arquivos.

ACIAM: Arquivo do Centro de Investigacións Agrarias de Mabegondo (A Coruña).

AHUS: Arquivo Histórico Universitario de Santiago.

AMB: Arquivo da Misión Biolóxica (Salcedo- Pontev.).

FPLS: Fondo privado de López Suárez (depositado no AHUS).

IPS: Instituto Padre Sarmiento (Santiago).

2. Organizacións e publicacións periódicas.

AF: A Fouce.

AG: Agricultura.

AMB: Arquivo da Misión Biolóxica.

ANT: A Nosa Terra.

AS: $\quad$ Acción Social (Mondoñedo).

BSPS: Boletín del Sindicato de Productores de Semillas.

COEN: Consejo Ordenador de la Economía Nacional.

EC: $\quad$ El Compostelano.

EFA: Estación de Fitopatoloxía Agrícola da Coruña.

EPG: El Pueblo Gallego (Vigo).

GA: Galicia Agraria (A Coruña).

GSA: Galicia Social Agraria (Mondoñedo).

JAE: Junta para Ampliación de Estudios.

MB: $\quad$ Misión Biolóxica.

PG: $\quad$ Partido Galeguista.

SPS: $\quad$ Sindicato de Productores de Semillas.

VG: La Voz de Galicia. 